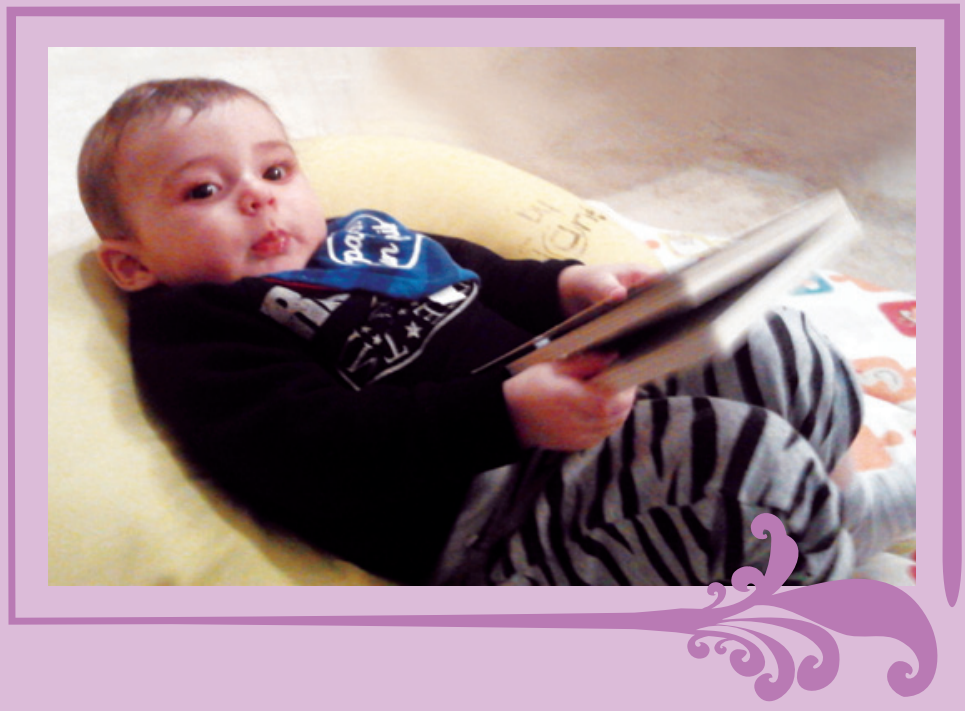

\author{
Breve \\ antología
}





\title{
Breve antología
}

\author{
JOSÉ CARLOS ROVIRA
}

Director de América sin nombre

Hubiera querido dedicar más espacio a esta «Breve antología», a esta selección indicada por varias personas que aparecen citadas y que se inicia con algunos textos que he leído con frecuencia y que cumplen de manera excelente con la motivación de este número de América sin nombre. Claro que podían haber sido centenares de textos los seleccionados, pero objetivos y exigencias editoriales nos hacen detenernos solo en algunos que nos llamaron la atención y nos la siguen reclamando.

Abre la antología «A Margarita Debayle» de cuyo autor, Rubén Darío, el próximo año 2016 conmemoramos el centenario de su muerte. Es un texto que forma parte de nuestra memoria infantil, y lo hace además porque era texto a memorizar en nuestras escuelas, y lo hacíamos pensando en el país de sueños, en la estrella que la princesa convierte en decoración de un prendedor y en su viaje al azul. Una vez soñamos con un rebaño de elefantes, y lo recitamos luego a los hijos, y el primer nieto observa a veces el tono riguroso que cambia en nuestra voz cuando le decimos, al trazar el recorrido celeste de la princesa, aquello de «mas lo malo es que ella iba/ sin permiso de papá». Sigue siendo un texto esencial en una «educación sentimental» que tuvo en este texto de Rubén, en otros más del mismo, o en los de La edad de oro de José Martí, una aportación latinoamericana de amplio impacto.

Abren la antología contemporánea dos capitulitos de Lilus Kikus de Elena Poniatowska, amiga nuestra que nos ha autorizado a reproducir estos fragmentos ejemplares de literatura infantil. A Elena no hay que presentarla aquí, ya que lo hicimos en esta misma revista con un monográfico que le dedicamos en 2008 (Elena Poniatowska: México escrito y vivido, $\mathrm{n}^{\circ} 11-12$ de América sin nombre). Sabemos que es Premio Cervantes de Literatura en 2014 y que es una de las figuras narrativas más importantes del castellano, y una de las voces más lúcidas de la protesta en México a lo largo de muchos años, hasta los más recientes, en los que la matanza de los 43 estudiantes de Iguala, en México, han provocado que elevase su voz, su denuncia y hasta su ira por estos acontecimientos terribles. Los dos fragmentos seleccionados de esta obra de 1954, de la que Juan Rulfo dijo aquello de «todo en este libro es mágico, y está lleno de las olas del mar o de amor como el tornasol que solo se encuentra, tan solo en los ojos de los niños» son la presentación de la chiquilla Lilus a través de sus juegos y una curiosa premonición narrativa de un tema tan actual y horrible como la violencia de género a propósito del asesinato a manos de su marido de Chiruelita, la amiga de Lilus.

Sigue Juan Villoro con un capítulo de esa novela para jóvenes extraordinaria, El libro salvaje, novela de iniciación a la lectura y a la pasión por la misma, a través del protagonista Juan, niño de 13 años, al que sus padres han dejado un verano en casa del tío Tito, acumulador de miles de libros en su domicilio y bibliógrafo imaginativo, al que se presenta en el fragmento seleccionado. Guiños culturales intensos y una historia de amor, o la demostración de que los libros acaban siendo espejos de nosotros, o la búsqueda de lo imprevisto, del libro desconocido, del imposible, 
son parte de una modélica actitud del novelista, que ha escrito excelentes obras para adultos como El disparo de Argón o Materia dispuesta, relatos y ensayos y crónicas. A Juan Villoro le dedicamos hace años una Biblioteca de autor en la Virtual Cervantes que puede servir de presentación más amplia para los lectores (http://www.cervantesvirtual.com/portales/juan_villoro/)

La mujer vampiro de la argentina María Teresa Andruetto es un juego con figuras del imaginario juvenil y con construcciones simbólicas de la historia. La autora, referente de la literatura argentina, ha escrito novelas, relatos y ensayos y ha obtenido prestigiosos premios como el Hans Christian Andersen en 2012 . El profesor Ramón Llorens, uno de los coordinadores de este número de América sin nombre, me afirma al proponérmela que su literatura abierta a un mundo amplio al margen de edades, tiene los temas de la dictadura, la solidaridad, la violencia, la construcción de la identidad y el universo femenino. Me invitó a conocer la amplitud de su obra, no sólo volcada en el universo infantil y juvenil, en el portal de nuestra Biblioteca Virtual (http://www.cervantesvirtual.com/portales/maria_teresa_andruetto/).

Guanaco blanco en la mitad de Francia me planteó desde la primera lectura aquella óptica geográfica que nos produce la imagen de un guanaco con su precisión espacial en pampas infinitas. La argentina Ana María Shua lo sitúa en un teatrillo en el Quartier latin, donde familias, un profesor, un coya que defiende a las vicuñas y los guanacos contra sus depredadores, un público atento, crean una historia divertida con conflictos, fuga de vicuñas y guanacos por la geografía parisina y un enigma final a propósito del estiércol de los animales. Pedro Mendiola, otro coordinador de este número, me hizo leer este relato de quien ha escrito poesía, teatro, novela, cuentos y microrrelatos. Entre sus libros infantiles y juveniles destacan: La fábrica del terror (1991), Ani salva a la perra Laika (1996), Las cosas que odio y otras exageraciones (1998), Planeta miedo (2002), El país de los miedos perdidos (2014) o El árbol de la mujer dragón (2013).

Leo por indicación de Carmen Alemany, subdirectora de esta revista, El expreso azul, un relato de Cecilia Eudave, una ficción en tiempos convulsos como los de la Rusia de comienzos de siglo, un extraño viaje obligado en un tren, el Transiberiano, el secuestro de un escritor llamado Verne, junto a un joven que le acompaña, la violencia de los secuestradores, su encuentro que explica la trama con el personaje que domina el motivo y quiere dominar el mundo, llamado Vladimir, que quiere que Verne trabaje para él, no por sus novelas imaginativas, sino por sus premoniciones científicas... Una ficción en tiempos revolucionarios y un amplio relato de una narradora y ensayista de quien tengo en mis manos ahora mismo un último libro, Diferencias, alteridades, identidad (Narrativa mexicana de la primera mitad del siglo $x x$ ) publicado por la colección de cuadernos de esta revista estos mismos días, porque Cecilia Eudave, aparte de narradora es ensayista y doctora en lenguas romances, profesora de la Universidad de Guadalajara (México), con varios libros de ficción imprescindibles y novelas y relatos juveniles de amplia trascendencia.

Cierra la breve antología un conjunto de breves poemas de María José Ferradas, una serie unificada con el título Guardianes, en los que la figura de cada guardián realiza la vigilancia sobre los árboles, la espuma, las palabras, la luz de la luna, el musgo, los pájaros, los recuerdos, la noche... Poesía de sensaciones entre naturaleza y memoria de quien es sin duda una voz joven y singular de la poesía chilena ganadora de varios premios, entre los que se encuentra el de Poesía infantil de la ciudad de Orihuela o el Marta Brunet, otorgado en 2014 por el Consejo de la Cultura y las Artes de Chile. 


\section{VIII \\ A MARGARITA DEBAYLE \\ RUBÉN DARÍO}

Margarita, está linda la mar, y el viento

lleva esencia sutil de azahar; yo siento

en el alma una alondra cantar:

tu acento.

Margarita, te voy a contar un cuento.

$$
* * *
$$

Este era un rey que tenía un palacio de diamantes, una tienda hecha del día y un rebaño de elefantes, un kiosco de malaquita, un gran manto de tisú, y una gentil princesita, tan bonita,

Margarita,

tan bonita como tú.

Una tarde la princesa vio una estrella aparecer; la princesa era traviesa y la quiso ir a coger.

La quería para hacerla decorar un prendedor, con un verso y una perla, y una pluma y una flor.

Las princesas primorosas se parecen mucho a ti: cortan lirios, cortan rosas, cortan astros. Son así. Pues se fue la niña bella, bajo el cielo y sobre el mar, a cortar la blanca estrella que la hacía suspirar.

Y siguió camino arriba, por la luna y más allá; mas lo malo es que ella iba sin permiso del papá.

Cuando estuvo ya de vuelta de los parques del Señor, se miraba toda envuelta de un dulce resplandor.

Y el rey dijo: «¿Qué te has hecho? Te he buscado y no te hallé; $\mathrm{y}$ ¿qué tienes en el pecho, que encendido se te ve?».

La princesa no mentía. Y así, dijo la verdad: «Fui a cortar la estrella mía a la azul inmensidad».

Y el rey clama: « No te he dicho que el azul no hay que tocar? ¡Qué locura! ¡Qué capricho! El Señor se va a enojar».

Y dice ella: «No hubo intento; yo me fui no sé por qué; por las olas y en el viento fui a la estrella y la corté».
Breve antología

RUBÉN DARÍO 


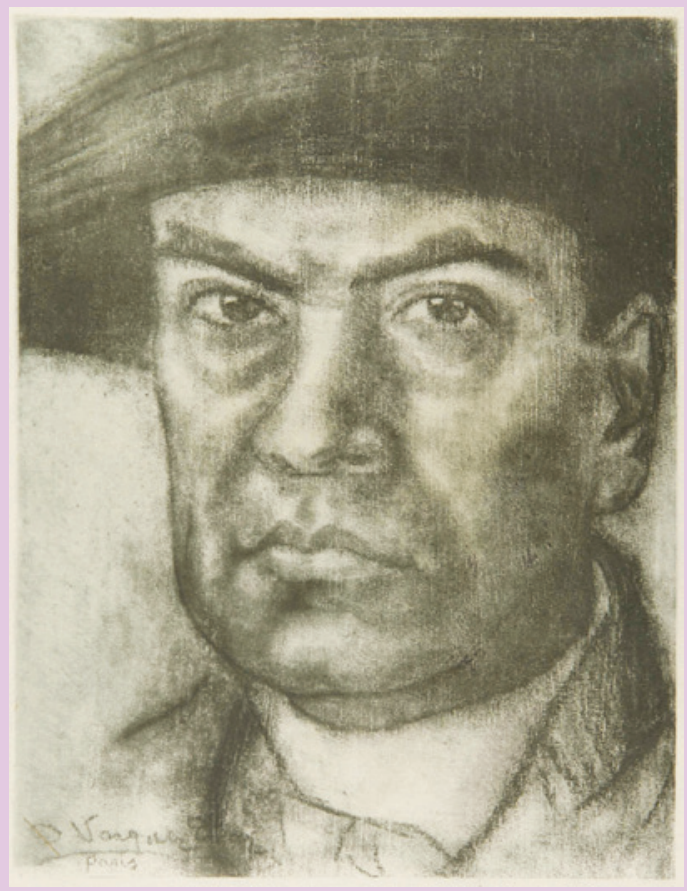

Y el papá dice enojado: «Un castigo has de tener: vuelve al cielo, y lo robado vas ahora a devolver».

La princesa se entristece por su dulce flor de luz, cuando entonces aparece sonriendo el Buen Jesús.

Y así dice: «En mis campiñas esa rosa le ofrecí: son mis flores de las niñas que al soñar piensan en mí».

Viste el rey ropas brillantes, y luego hace desfilar cuatrocientos elefantes a la orilla de la mar.

La princesita está bella, pues ya tiene el prendedor en que lucen con la estrella, verso, perla, pluma y flor.

$$
* * *
$$

Margarita, está linda la mar, y el viento

lleva esencia sutil de azahar: tu aliento.

Ya que lejos de mí vas a estar, guarda, niña, un gentil pensamiento al que un día te quiso contar un cuento. 


\section{Los juegos de Lilus* \\ ELENA PONIATOWSKA}

«Lilus Kikus... Lilus Kikus... ¡Lilus Kikus, te estoy hablando!».

Pero Lilus Kikus, sentada en la banqueta de la calle, está demasiado absorta operando a una mosca para oír los gritos de su mamá. Lilus nunca juega en su cuarto, ese cuarto que el orden ha echado a perder. Mejor juega en la esquina de la calle, debajo de un árbol chiquito, plantado en la orilla de la acera. De allí ve pasar a los coches y a las gentes que caminan muy apuradas, con cara de que van a salvar al mundo...

Lilus cree en las brujas y se cose en los calzones un ramito de hierbas finas, romerito y pastitos; un pelo de Napoleón, de los que venden en la escuela por diez centavos. Y su diente, el primero que se le cayó. Todo esto lo mete en una bolsita que le queda sobre el ombligo. Las niñas se preguntarán después en la escuela cuál es la causa de esa protuberancia. En una cajita, Lilus guarda también la cinta negra de un muerto, dos pedacitos grises y duros de uñas de pie de su papá, un trébol de tres hojas y el polvo recogido a los pies de un Cristo en la iglesia de Nuestra Señora de la Piedad.

Desde que fue al rancho de un tío suyo, Lilus encontró sus propios juguetes. Allá tenía un nido y se pasaba horas enteras mirándolo fijamente, observando los huevitos y las briznas de que estaba hecho. Seguía paso a paso, con gran interés todas las ocupaciones del pajarito. «Ahorita duerme... al rato se irá a buscar comida». Tenía también un ciempiés, guardado en un calcetín, y unas moscas enormes que operaba del apéndice. En el rancho había hormigas, unas hormigas muy gordas. Lilus les daba a beber jarabe para la tos y les enyesaba las piernas fracturadas. Un día buscó en la farmacia del pueblo una jeringa con aguja muy fina para ponerle una inyección de urgencia a Miss Lemon. Miss Lemon era un limón verde que sufría espantosos dolores abdominales y que Lilus inyectaba con café negro. Después lo envolvía en un pañuelo de su mamá; y en la tarde atendía a otros pacientes: la señora Naranja, Eva la Manzana, la viuda Toronja y don Plátano. Amargado por las vicisitudes de esta vida, don Plátano sufría gota militar, y como era menos resistente que los demás enfermos, veía llegar muy pronto el fin de sus días.

Lilus no tiene muñecas. Quizá su físico pueda explicar esta rareza. Es flaca y da pasos grandes al caminar, porque sus piernas, largas y muy separadas la una de la otra, son saltonas, se engarrotan y luego se le atoran. Al caerse Lilus causa la muerte invariable de su muñeca. Por eso nunca tiene muñecas. Sólo se acuerda de una güerita a la que le puso Güera Punch, y que murió al día siguiente de su venida al mundo, cuando a Lilus Kikus se le atoraron las piernas.

\begin{abstract}
Elena Poniatowska
Novelista y periodista mexicana nacida en París en 1932. Ha obtenido importantes premios entre ellos el Cervantes en 2013. Su amplísima producción contiene obras que son esenciales en la producción contemporánea, como su primera entada a la literatura infantil, Lilus Kikus, en 1954. Muchos libros avanzan títulos de creación y de crónica que son ya clásicos: Hasta no verte, Jesús mío, 1969, La noche de Tlatelolco, 1971, Querido Diego, te abraza Quiela, 1978, La Flor de lis, 1988, Tinísima, 1992, La piel del cielo, 2001...y medio centenar más hasta los últimos relatos, Hojas de papel volando, 2014. En 2008 le dedicamos el monográfico de esta revista Elena Poniatowka: México escrito y vivido ( $\left.\mathrm{n}^{\circ} 11-12\right)$. Ha tenido una amplia participación en luchas sociales en México como la más reciente y terrible, la desaparición de los 43 normalistas de Iguala por acción de los narcotraficantes en cuya denuncia no ha cesado.
\end{abstract}

Agradecemos a Elena Poniatowska la generosidad por autorizarnos a publicar dos fragmentos de su libro Lilus Kikus, publicado por primera vez en México en la editorial Los presentes y reeditado por la Editorial Era. 


\section{La amiga de Lilus}

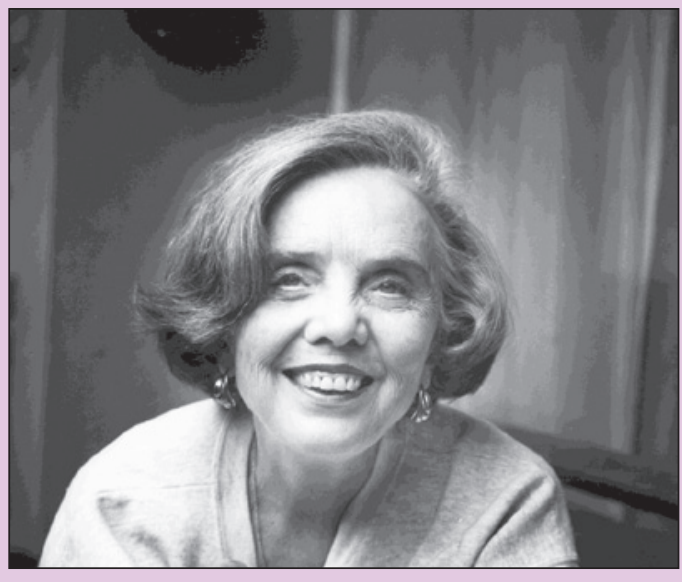

Lilus tenía una amiga: Chiruelita. Consentida y chiqueada. Chiruelita hablaba a los once años como en su más tierna infancia. Cuando Lilus volvía de Acapulco, su amiga la saludaba: ¿Qué tal te jué? ¿No te comielon los tibulonchitos, esos felochíchimos hololes?

Semejante pregunta era una sorpresa para Lilus, que casi se había olvidado del modo de hablar de su amiga, pero pronto se volvía a acostumbrar. Todos sus instintos maternales se vertían en Chiruela, con máxima adoración. Además, Lilus oyó decir por allí que las tontas son las mujeres más encantadoras del mundo. Sí, las que no saben nada, las que son infantiles y ausentes... Ondina, Melisenda...

Claro que Chiruelita se pasaba un poco de la raya, pero Lilus sabía siempre disculparla, y no le faltaban razones y ejemplos. Goethe, tan inteligente, tuvo como esposa a una niña fresca e ingenua, que nada sabía pero que siempre estaba contenta.

Nadie ha dicho jamás que la Santísima Virgen supiera algo de griego o latín. La Virgen extiende los brazos, los abre como un niño chiquito y se da completamente.

Lilus sabe cuántos peligros aguardan a quien trata de hablar bien, y prefiere callarse. Es mejor sentir que saber. Que lo bello y lo grande vengan a nosotros de incógnito, sin las credenciales que sabemos de memoria...

Las mujeres que escuchan y reciben son como los arroyos crecidos como el agua de las lluvias, que se entregan en una gran corriente de felicidad. Esto puede parecer una apología de las burras. Pero ahora que hay tantas mujeres intelectuales, que enseñan, dirigen y gobiernan, es de lo más sano y refrescante encontrarse de pronto como una Chiruelita que habla de flores, de sustos, de perfumes y de tartaletitas de fresa.

Chiruelita se casó a los diecisiete años con un artista lánguido y maniático. Era pintor, y en los primeros años se sintió feliz con todas las inconsecuencias y todos los inconvenientes de una mujer sencilla y sonriente que le servía té salado y le contaba todos los días el cuento del marido chiquito que se perdió en la cama, cuento que siempre acaba en un llanto cada vez más difícil de consolar.

Pero un día que Chiruelita se acercó a su marido con una corona de flores en la cabeza con prendedores de mariposas y de cerezas en las orejas, para decirle con su voz melodiosa: «Mi chivito, yo soy la Plimavela de Boticheli. ¡Hoy no hice comilita pala ti!», con gesto lánguido el artista de las manías le retorció el pescuezo. 


\section{El tío Tito}

JUAN VILLORO

Juan Villoro

Novelista y periodista mexicano, nacido en Ciudad de México en 1956, es autor de novelas como $\mathrm{El}$ disparo de argón, 1991, Materia dispuesta, 1997, El testigo, 2004 y Apocalipsis, 2014. Ha desarrollado una amplia producción de cuentos y presta una gran atención a la narrativa infantil y juvenil de la que El libro salvaje, 2008, es una muestra principal que ha tenido gran éxito de crítica y lectores. Su afición al fútbol, por la que ha obtenido varios premios periodísticos, tiene un libro principal de crónica, titulado Dios es redondo, publicado en 2006. A Juan Villoro le ha dedicado la Biblioteca Virtual Miguel de Cervantes una Página de autor (http://www.cervantesvirtual. com/portales/juan_villoro/) que contiene una muestra amplia de su producción narrativa y periodística.

Mi tío vivía en la parte antigua de la ciudad. En ese barrio, algunas casas eran derruidas con golpes de martillo para construir edificios modernos, otras estaban a punto de venirse abajo solas; otras más tenían amarrados los balcones para que no se fueran a pique y descalabraran a quienes caminaban por la calle.

En esta zona de derrumbes, que los adultos llamaban «el Centro», estaba la casa de tío Ernesto, da por Javier Martínez Meave conocido como «Tito» por la familia y como «don Tito» por los mensajeros que le llevaban los libry publicada en el año 2008 en conocido como "Tito» por la familia y como «don Tito» por los mensajeros que le llevaban los librosMéxico en Fondo de Cultura
que pedía a las más variadas librerías del mundo.
Económica. Agradecemos a los
autores la autorización para la

El tío vivía con tres gatos: uno era negro y se llamaba Obsidiana; otro era blanco y se llamabapublicación de este capítulo en Marfil; el hijo de ambos, mi favorito, era blanco con manchas negras y se llamaba Dominó.

América sin nombre.

Durante cincuenta y ocho años, el tío vivió sin otra compañía que sus libros y sus gatos. De pronto, para sorpresa de la familia, decidió que había llegado el momento de contraer matrimonio.

Estuvo casado durante un año con una señora de la que sólo recuerdo sus anteojos redondos y que estornudaba mucho por el polvo de los libros. En un momento de desesperación, aquella señora le dijo a mi tío: «No podemos vivir en este laberinto, soy alérgica a los papeles viejos». Mi tío le dio la razón: dejó la casa para los libros y se mudó con su esposa a un pequeño departamento. Pero la vida sin biblioteca fue muy triste para él, así es que decidió dejar a su esposa y volver con sus libros.

Por todo esto, me sorprendió mucho que me mandaran a su casa. El tío se sentía bien en soledad; no acostumbraba hacer fiestas ni reuniones, ni parecía necesitar otra compañía que sus tres gatos. ¿ Por qué había querido que yo fuera ahí? Todo era muy raro.

En mi maleta llevaba un libro: Todo sobre las arañas. Ya lo había leído y lo escogí precisamente por eso: me gustaba más volver a leer un libro estupendo que arriesgarme con uno desconocido.

Cuando llegamos a casa del tío, me gustó la cabeza de león que mordía una media luna de metal y servía para golpear la puerta.

Estaban derribando la casa de junto y eso provocaba mucho ruido. Nuestros toquidos apenas se oyeron. Mi madre me pidió que pateara con fuerza, pero como yo llevaba zapatos con suelas de goma no logré hacer mucho ruido. Por un momento tuve la esperanza de que mi tío no abriera nunca y yo pudiera regresar con mi madre. Justo entonces, la puerta se abrió.

- ¿Llevaban mucho tiempo tocando?

- preguntó el tío-. Adentro apenas se oye lo que pasa afuera.

Era cierto. En cuanto cerró el portón, se produjo un gran silencio, como si estuviéramos en el fondo del mar.

- He colocado aislantes especiales. Sólo así puedo concentrarme para leer - el tío me vio de frente, con ojos tan atentos que parecían a punto de salirse de su cara.

Tuve ganas de decirle: «No me veas así que no soy un libro», pero no me atreví.

En todas partes había libreros y volúmenes apilados en columnas que llegaban al techo.

- Vengan a la sala de estar - dijo el tío. 
La «sala de estar» era un cuarto un poco más despejado. Había libros en las paredes pero no en las sillas. Pudimos sentarnos ante una mesa donde un mapa servía de mantel. Australia me tocó justo enfrente. Dije que era mi país preferido.

-Estupenda elección, querido sobrino - comentó el tío-. No hay mucha cultura ni muchas antigüedades en ese rojo desierto, pero es la casa del ornitorrinco, el más fabuloso de los animales, un resumen biológico, una enciclopedia de lo que se puede ser sin serlo del todo: el ornitorrinco podría ser un pato, un castor o una marmota. Su secreto consiste en disfrazarse de otros animales para ser él mismo. Un gran actor de reparto.

No entendí nada. ¿El tío se habría vuelto loco en los últimos tiempos? Luego agregó, con mucho entusiasmo:

- Además, Australia tiene las mejores olas marinas, no tanto por su forma, sino porque bañan a las australianas, especie superior al ornitorrinco. En algún lugar tengo un calendario de australianas en bikini.

Mi madre vio al tío con preocupación y me tomó de la mano. Parecía arrepentirse de haberme llevado ahí. Las extrañas palabras del tío comenzaron a interesarme.

- ¿Quieren un té de pipa? - preguntó él, y salió del cuarto antes de que contestáramos.

- ¿Estarás bien aquí, Juanito? - mi madre me acarició el pelo y me vio con ojos tristes.

Ella me había dicho que necesitaba pasar unas semanas a solas para buscar un departamento más pequeño, ahora que éramos menos. No quise preocuparla más de lo que ya estaba, diciéndole que el tío me parecía medio loco. Interesante pero loco.

En un rincón de la sala distinguí una telaraña plateada, de forma triangular, idéntica a una ilustración de mi libro Todo sobre las arañas.

- Me gusta esta casa - le dije a mi madre.

- Si te sientes mal, me puedes hablar por teléfono.

Esto último no era tan sencillo. Para el tío, el teléfono era un error de la vida moderna. Odiaba que un timbre interrumpiera sus lecturas. «No quiero oír otra voz que mi conciencia», decía cuando alguien le preguntaba por qué no tenía teléfono.

- En la farmacia de enfrente puedes llamar - explicó mi madre-. Toma - me dio una bolsita con monedas para pagar las llamadas.

El tío regresó con una tetera humeante.

- Los viajes en barco no fueron en vano - dijo-. Gracias a las intrépidas tripulaciones que llegaron hasta la India y Ceilán, y a la estupenda costumbre de los capitanes de beber té, hoy podemos remojar estas hojas en agua caliente. Huelan, queridos parientes:

¿quieren té de humo?

El tío Tito sirvió antes de que le contestáramos. El té, en efecto, olía a pipa.

— «Lapsang Soo-shang», así se llama esta rica variante.

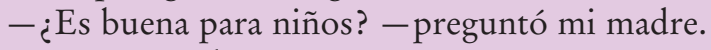

- Bueno, yo diría que Juan ya no es un niño - opinó el tío, y me cayó mejor.

Bebimos el curioso té hasta que mi madre dijo que necesitaba hablar a solas con Tito.

El tío propuso que yo revisara la casa mientras ellos conversaban. Me entregó una campanita:

- Si te pierdes - explicó-, agita la campana y llegaré en tu auxilio.

¿Era posible perderse dentro de una casa? En unos minutos descubriría que sí, y de qué manera.

Caminé por un pasillo rodeado de libreros y entré en la primera habitación a mi alcance. Era un cuarto de doble altura, cubierto de libros de pared a pared, rodeado por un balcón con escalerilla, que permitía llegar a los libros del segundo piso.

Seguí rumbo a otra recámara, sin ver otra cosa que libros.

De pronto Dominó saltó desde un anaquel y se escurrió por una puerta. Lo seguí y me encontré en un corredor oscuro. Traté de dar con el interruptor de la luz, pero mis manos sólo tocaron volúmenes empastados en cuero. Tropecé con libros que estaban en el piso. Volví a buscar el interruptor de la luz y de pronto creí encontrarlo. Toqué una pequeña palanca y la jalé hacia abajo. Una trampa se abrió bajo mis pies y caí por una resbaladilla hasta un depósito de sábanas en el que también había algunos libros. Por suerte no había perdido la campanilla. La agité con fuerza hasta que llegó mi tío.

- ¿Qué haces en la lavandería, sobrino? - me preguntó. 


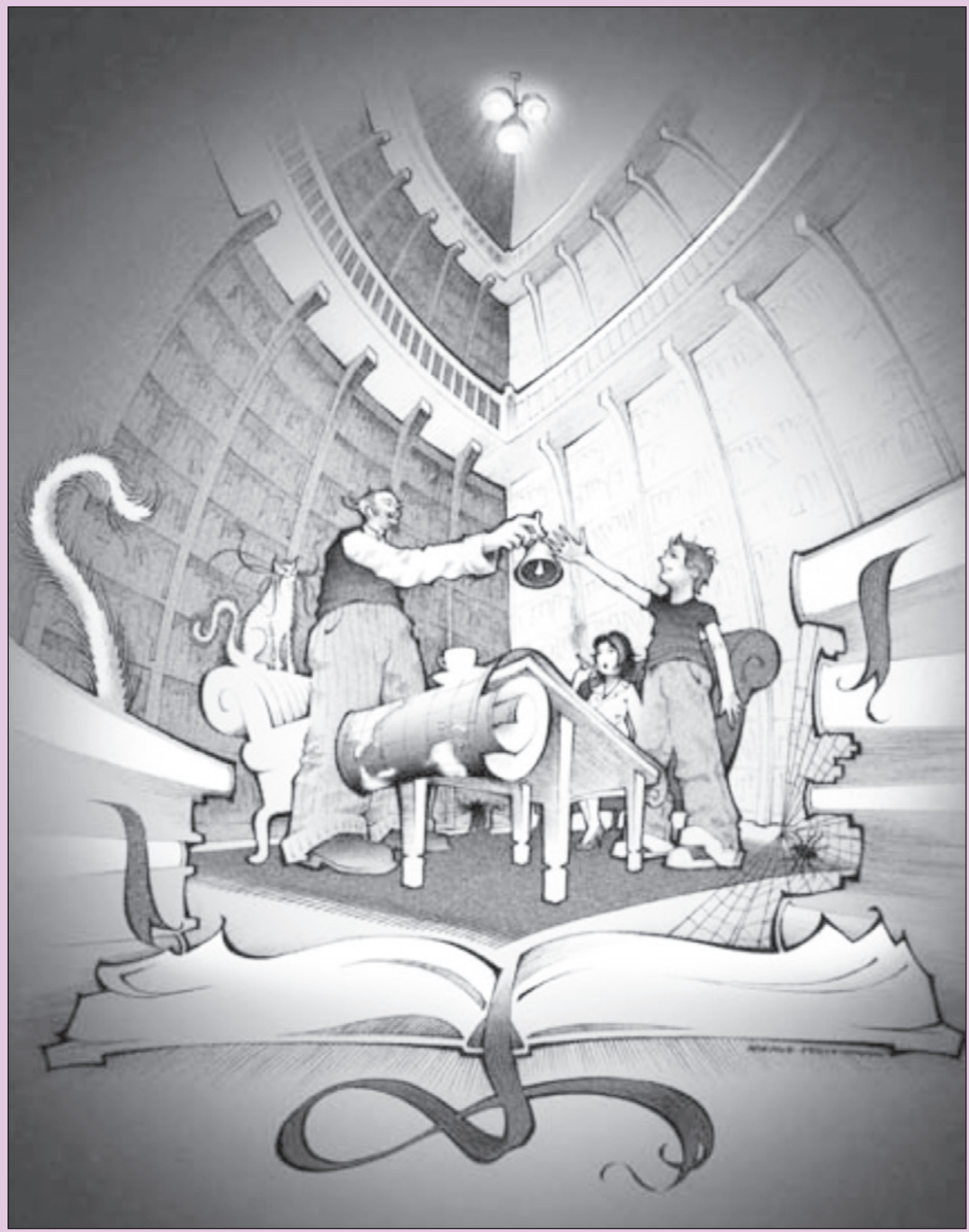

- Me caí desde allá arriba.

- Ya te irás acostumbrando a la casa. Tiene muchos recovecos, pero es bastante práctica. Ya descubriste el camino de la ropa sucia.

- Aquí hay algunos libros.

- Son para secado y planchado. A veces se me derrama el té sobre las páginas.

Cuando regresamos a la sala, mi madre se veía muy tranquila. Le había hecho bien hablar con el tío.

- Ya vimos la utilidad de la campana - dijo Tito-, nunca te separes de ella. Te aconsejo que te la amarres muy bien. Tengo un libro de nudos y te recomiendo el que se llama Margarita: Una vez atado, ni Dios lo quita - recitó.

Mi madre se despidió con muchos besos y abrazos. Olí su pelo, el mejor olor del mundo. 
Ella me recordó que le hablara de vez en cuando desde la farmacia de enfrente.

Cuando el tío y yo nos quedamos solos, me dijo:

- Muy bien. Ahora propongo que pongamos en práctica el método del famoso detective Sherlock Holmes para conocer personas: vamos a hablar de nuestros defectos. ¿Cuáles son los más graves que tienes, sobrino?

-No sé.

- Para vivir con alguien tienes que saber qué problemas te puede dar. Nadie es perfecto. Si aceptas esos problemas te llevarás bien.

- No se me ocurre nada.

- ¿No serás un poco presumido? Todos tenemos nuestros defectillos. Está bien. Empezaré yo - hizo una pausa, bebió un largo sorbo de té de pipa y empezó a enlistar sus defectos -: Uno: ronco en las noches, esto no es grave porque tendrás tu propio cuarto; dos: no me gusta que me hablen cuando estoy leyendo; tres: no soporto que alguien cante; cuatro: me enojo mucho por cosas que no tienen importancia, pero se me pasa rápido, y cinco: hago mal las cuentas y me quedo con monedas de otras personas...

Esto último hizo que me preocupara por mis monedas para hablar por teléfono. Las tendría que esconder muy bien.

- Ahora te toca a ti -insistió el tío.

-A veces tengo pesadillas y grito en la noche - contesté-; también me dan calambres en las piernas; no soy muy ordenado y tiro la ropa en el suelo; me lavo mal las manos y a veces las tengo pegajosas; me distraigo cuando estoy pensando y no oigo bien lo que me dicen; soy torpe y rompo las cosas...

Nunca había pensado que tuviera tantos defectos, pero me hizo bien decirlos.

- Puedo vivir con todo eso - opinó el tío, muy reflexivo-. ¿Y tú?

¿Puedes con mis defectos?

-Sí.

- Perfecto. Esos problemas nos unirán mucho.

El tío me dio un abrazo y, al hacerlo, volcó su taza de té. Unas gotas fueron a dar a su pantalón.

- ¡Maldita sea! - gritó con furia; luego se me quedó viendo-:

¿Lo ves? Me enojo por cosas que no importan. Pero se me pasa en un santiamén. Los problemas que en verdad valen la pena me llaman la atención, pero no me preocupan. He leído suficientes libros para que sea así: los escritores me enseñaron que los grandes problemas son interesantes.

$-¿$ Te gustan las arañas, tío? -le pregunté.

$-¿$ Por qué lo dices?

Señalé la telaraña triangular en el rincón del cuarto.

-En esta casa hay arañas inofensivas que protegen de los mosquitos. ¿Has tratado de leer mientras un mosquito zumba en tu oído? Odio los mosquitos: son las orquestas de la desesperación. Zumban y zumban y no puedes pensar en otra cosa. En cambio, las arañas son amigas del silencio: se comen a los mosquitos con todo y su música.

- Traje un libro que se llama Todo sobre las arañas - le dije.

- Estás en el lugar correcto para estudiar a las que no son venenosas.

El tío Tito puso una mano en mi hombro y agregó:

- Lo vas a pasar bien aquí - luego suspiró como un nadador antes de lanzarse al agua-: lo vamos a pasar bien. Esta casa necesitaba un joven cerebro. Tus sesos son bienvenidos.

Así comenzó mi temporada en el laberinto de los libros. 


\title{
La mujer vampiro'
}

\author{
MARÍA TERESA ANDRUETTO
}

\author{
María Teresa Andruetto \\ (Arroyo Cabral, 1954) \\ María Teresa Andruetto es un re- \\ ferente de la literatura argentina. \\ Autora de novelas, cuentos, poe- \\ sía, ensayo y literatura para niños \\ y jóvenes, ha recibido numerosos \\ premios entre los que destacan el \\ Hans Christian Andersen, conside- \\ rado El Pequeño Nobel y el Premio \\ Iberoamericano a la Trayectoria \\ en Literatura Infantil de la edito- \\ rial SM. Sus novelas tratan de la \\ dictadura, de la solidaridad, de la \\ violencia, la construcción de la \\ identidad individual y social y del \\ universo femenino.
}

\section{Primera parte}

Hace ochenta años, en la ciudad inglesa de Blackburn, una mujer fue acusada de vampiro.

La mujer se llamaba Sarah Ellen, estaba casada y tenía dos hijos. Era rubia como una muñeca rubia, tenía la piel muy blanca y en la cabeza, una cascadita de rulos.

Cierta vez, alguien creyó ver en su cuello una marca oscura y entonces dijo, en serio o en broma, que tal vez la había mordido Drácula, y así, unos por otros, todos empezaron a considerar que se trataba de una mujer vampiro.

Tanto se dijeron estas cosas aquí y allá, que se enteraron del asunto las Mujeres Honradas de la Ciudad de Londres, y escandalizadas informaron a las máximas autoridades de la iglesia que a una mujer de Blackburn llamada Sarah Ellen la había mordido Drácula.

Enteradas de esto, las máximas autoridades de la iglesia presionaron al obispo.

El obispo presionó al pastor de Blackburn. Y el pastor de Blackburn, acorralado, dijo que, a su parecer, la gente tenía razón, y que la mancha en el cuello de Sarah Ellen debía ser, en verdad, la marca de un beso de

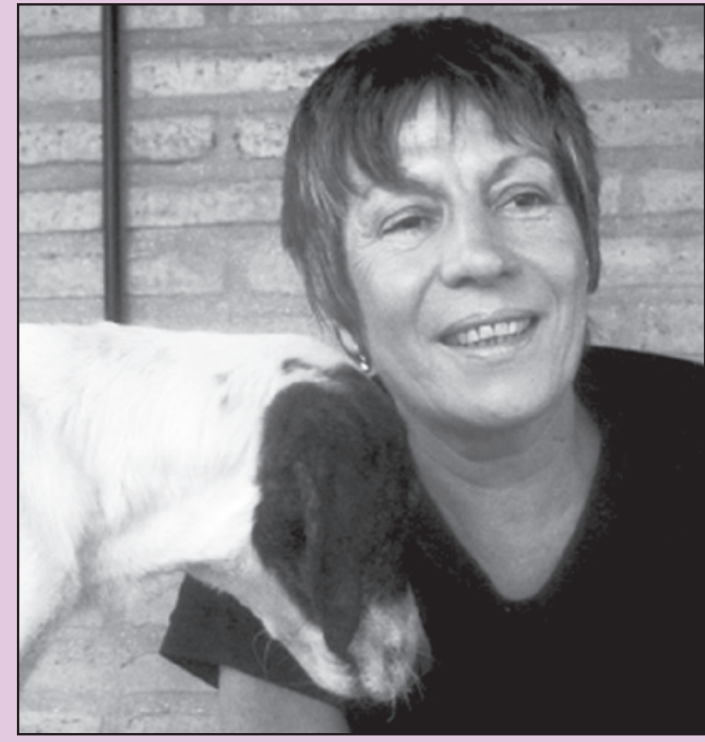
Drácula. Ella rió maliciosa y su marido gritó a quien quisiera oírlo que nada de lo que decían era cierto, que todo era una ridícula patraña, que lo único cierto era que su mujer tenía la piel muy blanca, y que era hermosa, la más hermosa de Blackburn.

Pero nadie quiso oírlo.

Y a ninguno, ni al pastor ni a los vecinos ni al obispo, se le movió un pelo cuando las autoridades del pueblo y de la iglesia juzgaron a Sarah Ellen y la condenaron a muerte.

A morir con el corazón atravesado por una estaca.

El verdugo del condado hizo lo que le mandaron que hiciese, sin que lo inmutaran los gritos de los hijos ni el dolor del marido ni los ojos húmedos de ella ni el escupitajo que le dio cuando él se acercaba con la estaca en la mano.

El escupitajo y la amenaza:

Esté donde esté, resucitaré en ochenta años convertida en vampiro y clavaré mis colmillos en los nietos de ustedes.

Pero el verdugo hizo su trabajo, la mató sin piedad.
1 Publicación original: Buenos Aires, Sudamericana, 2001, pp. 30-38. Reproducido de: http:// www.cervantesvirtual.com/ obra/la-mujer-vampiro/. 
Las cosas no terminaron ahí: la gente no quiso que enterraran a Sarah Ellen en el cementerio de Blackburn y entonces el marido tuvo que cargar con el cadáver de su mujer, meterlo en una caja de madera, echarla sobre un carro e irse con los hijos y la muerta a otra parte.

Así viajaron con el carro y el cadáver de Sarah Ellen hasta Liverpool, pero en Liverpool le dijeron que no, que ahí no podían enterrarla.

Y se lo dijeron en Manchester.

Y en Boston.

$\mathrm{Y}$ en Bath.

Y en Weston.

Y en Londres.

Andando de un sitio a otro, descubrieron que podían pedir unas monedas a cambio de dejar que los lugareños miraran el féretro maldito con la maldita muerta.

Y así comenzaron a ser ellos los que anunciaban que tenían sobre el carro a una mujer endemoniada, a una vampira.

Cierto día el hombre sacó una foto de Sarah Ellen que tenía guardada, le dibujó unos colmillos y la colocó sobre el cajón.

Más tarde los hijos pintaron unas manchas rojas sobre una tela blanca para agitarla como una bandera cuando llegaran a un sitio.

$\mathrm{Y}$ en algún momento compraron por el camino varias ristras de ajo y las colgaron a los costados del carro.

De ese modo recorrieron Inglaterra.

Toda Inglaterra.

Pero como en ninguna ciudad consiguieron un lugar donde dejarla, y ya los hijos se hicieron grandes y algo viejo se hizo el hombre, acabaron por tomar un barco de carga y, con féretro y todo, se vinieron a América.

Entraron por el puerto de Buenos Aires

y anduvieron por Adrogué,

por Berazategui,

por Ayacucho,

por Coronel Suárez

y por General Villegas.

Después pasaron por Wenceslao Escalante,

por Isla Verde,

por Alcira Gigena.

Y más tarde por Berrotarán,

Corralito,

La Bolsa y San Agustín.

Siempre con la misma historia y con el mismo pedido de permiso, hasta que en un pequeño pueblo 11 mado Tío Pujio les dijeron que sí.

Habían andado tanto tiempo con el cadáver al hombro, que hasta se hubiera podido decir que tenían armada la vida de esa manera, y que ya no estaban seguros de querer dejar a la muerta en ninguna parte.

¿Asi que puede quedarse?, preguntó el marido en Tío Pujio.

Sí,

le contestaron.

¿Aunque se trate de una vampiro?, preguntó uno de los hijos.

Sí,

le contestaron.

¿Aunque resucite y nos muerda a todos?, preguntó el otro hijo. 
le contestaron,

porque ni al intendente ni a los habitantes de Tío Pujio parecía importarles nada.

De modo que la enterraron.

Sólo el padre y los hijos, sin ceremonia alguna.

Y después salieron del cementerio y se perdieron por las callecitas del pueblo o por el mundo, que para perderse es la misma cosa.

No bien desaparecieron de Tío Pujio el marido y los hijos de la inglesa, la gente hizo pintar un cartel que decía, en grandes letras rojas:

\section{EN ESTE PUEBLO ESTÁ ENTERRADA UNA MUJER VAMPIRO}

Acérquese al almacén de ramos generales y averigüe. Su pregunta no nos molesta.

Después montaron el cartel sobre una estructura de hierro y lo colocaron a la entrada del pueblo, mirando hacia Villa María, sobre la Ruta N. ${ }^{\circ}$ 9. De modo que todos los habitantes del pueblo y los viajeros que pasaban por la ruta, supieron que en aquel cementerio habían enterrado a una muerta maldita, a una vampira.

\section{Segunda parte}

Muchos años más tarde, cuando estaba a punto de cumplirse la maldición de Sarah Ellen y ya no vivían en este mundo ni el marido ni los hijos, la gente se apretujó en el cementerio de Tío Pujio para ver a la mujer vampiro sentarse en la tumba, y se produjo tal descalabro que fue necesario un cordón policial para que los vivos no alteraran la paz de los muertos.

Un informe de urgencia pidió por la radio, poco antes del día señalado, que todas las mujeres embarazadas se fueran a otra parte, por miedo a que Sarah Ellen resucitara y murieran de miedo, en los vientres, los hijos por nacer.

La tarde del aniversario de la muerte de Sarah Ellen, cerca de trescientas personas de todas las edades, con excepción de las embarazadas y los niños pequeños, se las habían ingeniado para llegar junto al nicho donde estaba enterrada la mujer vampiro.

Unas horas antes de la medianoche, cerca de una decena de luces y equipos de televisión de Villa María, Córdoba y Buenos Aires alumbraron la lápida, custodiada por cuatro policías. Y mostraron al mundo que aquella lápida no tenía cruces ni estrellas de David ni mensajes de amor ni floreritos, como tienen las lápidas, sino apenas dos fechas que marcaban el comienzo y el final de la vida de Sarah Ellen y una foto pequeña en la que la inglesa reía, con largos colmillos dibujados, bajo su cascadita de rulos.

Mientras esperaban que el reloj de la iglesia diera las doce de la noche, algunas personas hacían ritos para que la maldición no se cumpliera y otras parecían esperar ansiosas que se cumpliera.

Así, hubo quienes caían de rodillas junto al nicho.

Y quienes arrojaban, sobre los mausoleos cercanos, pétalos empapados en agua bendita.

Y quienes rezaban a viva voz el rosario y las letanías a la Virgen.

Y quienes llevaban en los brazos una muñeca rubia que representaba a Sarah Ellen.

De pronto se escuchó un ruido extraño que venía de alguna parte: de atrás de un carrito donde un hombre vendía praliné. O de un puesto de choripanes, instalado a la entrada del cementerio. O del sitio donde una mujer gorda ofrecía muñecas con estacas clavadas a la altura del corazón y colgantes con colmillos.

Pero era un ruido solamente, porque ver, nadie vio nada.

Y entonces, cuando ya casi todos se habían cansado de esperar, un hombre dijo que el alma se le había desprendido del cuerpo y había entrado en la tumba de Sarah Ellen, y que la estaca de madera con que alguna vez la habían matado a ella ahora se había convertido en hueso.

Y luego lo dijo otro.

Y luego otro más. 
Hasta que, uno por otro, todos los que allí estaban lo repitieron. Porque todos querían estar cerca, más cerca que ninguno, del espíritu de aquella muerta.

Así se multiplicaron varias veces en una sola noche las ventas de crucifijos y de estacas, de hueso, de plata, de madera. Y el olor a ajo con que se ahuyenta a las brujas se desparramó por el pueblo. Y las cintas rojas contra la mala suerte colgaron de los cuellos de la gente. Y la ruda macho que defiende de los maleficios perfumó todo Tío Pujio.

Pero la medianoche llegó y no sucedió nada.

Impacientes, los que allí estaban esperaron un poco más.

Hasta la una,

hasta las tres,

hasta las cinco de la mañana.

Y luego, viendo que por más que pasaran las horas nada sucedía, cada uno empezó a caminar hacia su casa llevando en las manos los colmillos de plástico y las cruces doradas.

Justo cuando el cielo comenzaba a clarear con pinceladas rojas, como de sangre. 


\section{Guanaco blanco en la mitad de Francia 1}

ANA MARÍA SHUA

Allí estaba el indio coya, subido al escenario, chiquito, morocho, todo vestido de castaño, color vicuña, hasta confundirse casi con la pared del fondo. Parecía haberse olvidado del micrófono que tenía prendido en el poncho y hablaba en voz baja, mirando para el otro lado, de modo que no se lo escuchaba bien.

El acto había sido convocado por OFALA, la Organización por la Fauna de África, Latinoamérica y Asia. No era una organización muy importante, sino una más de todas las agrupaciones ecologistas que actuaban en París. Los europeos, o por lo menos algunos europeos, se preocupaban mucho en esa época por la preservación de la fauna y la flora silvestres de los países pobres. Pero

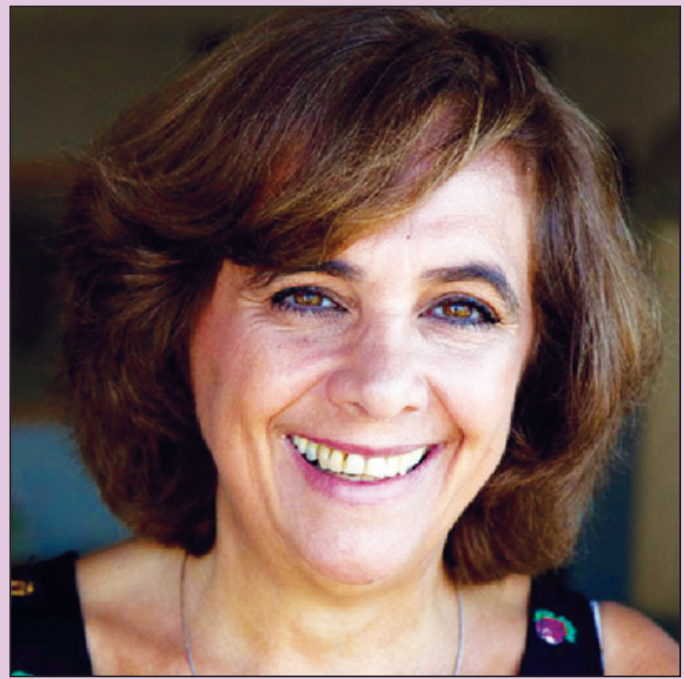
no les decían países pobres ni tampoco Tercer Mundo, porque les parecía que, siendo ellos el Primer Mundo, llamarlos «terceros» sonaba un poco despreciativo, de manera que cada vez que tenían que referirse a esa parte del mundo, mencionaban los continentes completos: América Latina, Asia y África.

El acto se hacía en un teatrito chico y pobre del barrio de la Universidad, el Quartier Latin. En lugar de butacas había sillas, el escenario era redondo, sin telón, pero los equipos de iluminación y sonido funcionaban muy bien.

Un profesor de la Sorbonne traducía al francés lo que decía el coya. Su voz resonaba con fuerza, la sala estaba llena y los participantes parecían muy interesados. Aplaudían y gritaban consignas en las partes más conmovedoras del discurso.

El profesor era un hombre mayor, con una gran cabeza y una barba blanca. Con su cara de prócer de libro de historia parecía muy acostumbrado a mantener la atención de sus alumnos. Era un excelente intérprete simultáneo. Como un buen actor, le daba énfasis y sentimiento a sus palabras, mucho más que el coya, que hablaba en forma monótona y aburrida, como si estuviera repitiendo algo que ya había dicho muchas veces sin grandes resultados.

Después de las primeras miradas de curiosidad, la mayoría de la gente se había olvidado del coya y mantenían la vista fija en el profesor, a pesar de que el foco de luz no lo iluminaba a él.

- ¿Está traduciendo bien? -preguntó la francesita Lou, a Axel, su amigo casi argentino.
Ana María Shua

Escritora argentina. Ha cultivado todos los géneros literarios (poesía teatro, novela, cuentos y microrrelatos), tanto para el lector adulto, como para el público infantil y juvenil. Su obra literaria ha sido galardonada con prestigiosos premios literarios internacionales. Entre sus libros infantiles y juveniles destacan: La fábrica del terror (1991), Ani salva a la perra Laika (1996), Las cosas que odio y otras exageraciones (1998), Planeta miedo (2002), El país de los miedos perdidos (2014) o El árbol de la mujer dragón (2013)
Publicado originalmente en Miedo en el Sur (1994), para lectores a partir de 11 años. 
Los chicos habían asistido al acto con sus padres, dos matrimonios amigos que querían hacer participar a sus hijos en la defensa de las reservas del planeta.

- No sé, no tengo la menor idea -le contestó Axel-. El coya está hablando en quichua.

- ¿Y por qué tú no sabes quichua?

(En este punto hay que recordar que los chicos hablaban en francés, de modo que esta es una traducción de su diálogo).

- ¿Y por qué no lo sabes tú? - contestó Axel, un poco molesto. - En Argentina se habla español, hay pocos grupos indígenas que todavía mantengan su idioma.

El tema del acto era la caza y depredación de la vicuña y el guanaco, dos especies del noroeste argentino pero también de Bolivia y Perú, que se encontraban en peligro de extinción. El coya había empezado citando cifras concretas aportadas por la Fundación de Vida Silvestre que mostraban cómo se habían reducido las manadas en los últimos 30 años, a causa de la caza indiscriminada.

- ¿Has cazado tú un guanaco alguna vez cuando vas de vacaciones a la Argentina? - preguntó Lou.

- Yo conozco a los guanacos tanto como tú - dijo Axel-. ¡Los he visto en el zoológico!

Los padres de Lou parecían muy interesados en todo lo que estaba sucediendo y tomaban apuntes en unas libretitas. En cambio los padres de Axel parecían de mal humor y hablaban entre ellos en argentino.

-Qué querés que te diga, che, a mí me cae remal que se hayan traído a un coya para exhibirlo como si fuera un guanaco - decía la madre.

-Este es coya como yo, debe ser un actor iraní disfrazado que se aprendió el discurso en quichua - comentó el padre.

Y los dos, igual que Axel, parecían muy preocupados porque no se los confundiera con el indio coya, que seguía desgranando datos aburridísimos acerca de la cacería indiscriminada de fauna silvestre. Al profesor francés cada vez le daba más trabajo mantener a la gente interesada y comprometida con lo que se estaba diciendo.

- ¿Quiénes son los infames que cazan a las pequeñas vicuñas? - preguntó Lou en voz baja.

Ella pensaba en norteamericanos como los de las películas, con ametralladoras automáticas y cargadores de balas cruzados en el pecho. Hombres que seguramente ganaban millones de dólares con el comercio de pieles. Por eso la desilusionó la respuesta de Axel:

-Ellos son pobres tipos como este, que consiguen apenas monedas. Hasta algunos cazan para comer. Los negocios que venden artículos para turistas, esos sí ganan algo más.

Parecía que el coya lo hubiera escuchado a Axel, porque de eso precisamente estaba empezando a hablar.

-Y yo digo - traducía el profesor al francés - que hay distintas maneras de cazar, unas están bien y otras que no lo están. ¡Así se puede cazar! (Observen por favor el instrumento que está mostrando) Con estas boleadoras que se llaman libes. Rodeando a las manadas con hilo rojo, espantándolas con trapo rojo y después atrapándolas con este arma arrojadiza tradicional. Con arma de fuego no, está prohibido. Porque si matan muchos animalitos, y más las crías, después no crecen las manadas. Las crías tardan un año en formarse en el vientre de las madres, no se matan madres embarazadas.

Uno de los participantes levantó la mano para hacer una pregunta. El profesor, que era el que conducía el acto, quiso que le pasaran el micrófono, pero le costó convencer al coya de que se callara. Parecía tener miedo de no poder seguir si lo interrumpían, como quien se aprendió de memoria algo que no entiende bien.

-Quisiera saber - dijo, hablando en español, el que preguntaba - cuáles son los organismos o instituciones que prohíben la caza de la vicuña y el guanaco.

El profesor tradujo la pregunta al quichua. Los padres de Axel, muy indignados, le comentaron a los padres de Lou que la traducción les parecía una payasada, porque aún los indígenas que hablaban quichua era bilingües y conocían perfectamente el español. Los padres de Lou asintieron solidarios, pero querían escuchar la respuesta.

Lo que sucedió fue extraño. Al escuchar la pregunta, el hombrecito moreno pareció cambiar de actitud. Se enderezó pomposamente, echó una mirada despreciativa al público de 
franceses y latinoamericanos y dio una respuesta completamente inesperada... en excelente francés.

- ¡Soy yo quien lo prohíbe!

Todos sonrieron un poco incómodos, en parte por el buen francés y en parte porque parecía que el hombrecito no estaba bien de la cabeza.

-Disculpe - le preguntaron otra vez-. ¿Pero podría decirnos quizás quién es usted? ¿Tal vez el funcionario encargado de la protección de la fauna silvestre en su país? $¿ \mathrm{O}$ en su provincia? ¿En su pueblo?

- ¡Soy yo quien lo prohíbe! ¡Porque yo soy quién para prohibirlo! Porque si matan a las madres, ¿quién junta a las crías y las cuida para que no mueran? ¿Quién debe persuadir a la madres vicuñas, a las madres guanacas que le den de mamar a las crías ajenas, huerfanitas? ¡Soy yo el que debo!

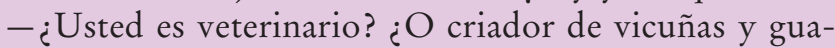
nacos domésticos?

$-¡$ ¡Y soy El Yastay, Coquena soy! - gritó el coya-.


Yo soy el Amo de las Vicuñas y los Guanacos, yo soy el que conduce a los rebaños, invisible en el viento! ¡Yo me convierto en Relincho, en Guanaco Blanco que avisa y protege cuando llegan los cazadores! - El coya gritaba, y su voz enorme llenaba todo el teatro haciendo vibrar las paredes.

- Parece que por fin se acordó dónde tenía el micrófono - comentó el papá de Axel.

Pero Axel y Lou, que estaban muy atentos, le hicieron notar que al contrario, con el entusiasmo (el coya ahora movía los brazos levantándolos hacia arriba como para invocar a los dioses) el micrófono se le había desenganchado del poncho y estaba tirado en el suelo.

- Yo soy el que ayuda a los que cazan bien. Vicuñas y guanacos protejo y también a los cazadores, jellos también son pobres, perseguidos, ellos también son mis hijos, ellos también están en vías de extinción!

El profesor francés lo miraba con la boca abierta. Parecía un actor que cree estar interpretando una obra y de golpe se da cuenta de que los demás actores están recitando un texto desconocido.

Con el coya pasaba algo muy extraño. Al principio parecía más alto solamente porque se había enderezado, pero ahora era imposible negar que estaba empezando a crecer. Ya se lo veía bastante más alto que al profesor de la Sorbonne. La gente estaba fascinada. Aplaudía y gritaba enloquecida.

- A los malos no ayudo, no. A los que encierran al rebaño en una angostura y tapan las salidas y matan con armas de fuego, a esos no ayudo. A los que matan por diversión, a esos no ayudo, a esos pierdo, a los perros mato, a los hombres pierdo, ipara que mueran de hambre perdidos los dejo! ¡A los que les importa más los guanacos que la gente, a esos tampoco ayudo!

Muchos participantes empezaron a moverse incómodos en sus asientos. El administrador del teatro parecía francamente preocupado. Le dio una orden en voz baja a los que manejaban los equipos de sonido y las luces. Pero lo único que consiguió es que se apagaran los chirridos artificiales de los aparatos. La voz del coya seguía llenando todo el teatro con su resonancia extraña, y una luz brillante que parecía partir de él y volver a él mismo iluminaba todo el lugar.

El camarógrafo del canal de cable grababa apasionadamente tratando de no perderse ninguna imagen. Un periodista que estaba con él le indicaba cuándo mandar la cámara sobre las caras asombradas o alteradas del público. También siguieron con la cámara al administrador del teatro cuando fue hasta la puerta a hablar con los hombres de seguridad. La madre de Axel también se había dado cuenta. Se puso muy nerviosa y empezó a tironear a los demás para convencerlos de que salieran todos de allí.

Pero Axel y Lou no querían perderse nada. Parecía que recién ahora iba a empezar lo bueno. Dos hombres grandotes se subieron al escenario con la intención de hacer bajar al coya. El 
profesor francés ya había desaparecido mezclado con los participantes. Pero el indígena ahora era un verdadero gigante. Su ropa había crecido con él. Su poncho de vicuña parecía flamear con un viento propio. Con un pie calzado con ojotas de cuero de guanaco, le dio una patada en la barriga a uno de los grandotes (que parecía chico al lado del gigante moreno). Al otro lo boleó con sus libes (esas boleadoras especiales) antes de que alcanzara a trepar y lo hizo caer sobre los espectadores con las piernas atadas.

- ¡El Yastay soy yo, soy el Coquena! — volvió a gritar-. ¡Animalitos, vengan a mí! ¡Yo soy el que los cuida y el que los manda!

Como salidos desde abajo de la tierra, como si atravesaran las paredes, como si se materializaran en el aire, un enorme rebaño de vicuñas y guanacos empezó a llenar todos los espacios libres del local. Miraban a los espectadores con sus grandes ojos negros y mansos. Axel y Lou acariciaron a una vicuña que los empujó amablemente con la cabeza, mientras sus padres, asustados pero no en pánico, trataban de hacerlos salir antes de que se produjera una peligrosa estampida de personas y animales.

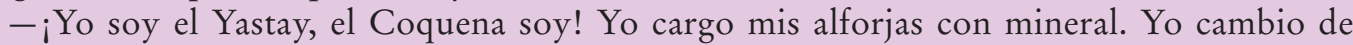
lugar la plata para engañar a los hombres. ¡Víbora viva es mi látigo, víboras son mi arreos! ¡A las alforjas, mineral! - gritaba el coya.

En efecto, las monedas de 10 y 20 francos empezaron a salir mágicamente de los bolsillos de la gente y a llenar las alforjas de las vicuñas, atadas a sus lomos con víboras vivas que sacaban amenazadoramente sus lenguas vibrantes.

Había quien se divertía con lo que estaba pasando y otros corrían aterrados hacia la salida. El camarógrafo trataba de no perderse nada. El periodista sacó un teléfono celular y empezó a hablar a gritos para hacerse oír en medio de lo que era ya nada más que confusión y tumulto. El administrador del teatro le arrancó el teléfono para llamar a la policía.

- Animalitos míos, vicuñitas, guanaquitos, allá nos vamos - seguía gritando el gigante, ahora en perfecto castellano con tonada norteña-. ¡Síganme animalitos, a la calle, a la llanura, a buscar nuestros cerros vamos!

Y de pronto ya no se lo vio más. En cambio todos los animales salieron en estampida del teatrito, seguidos por los pocos participantes que quedaban adentro. Los demás estaban reunidos en la calle.

Las vicuñas y guanacos, separados en dos grupos y guiados por un enorme guanaco blanco que parecía conocer el camino, se echaron a correr por el empedrado de la Rue Saint-Jacques. Ya habían llegado varios patrulleros, y policías en moto que se lanzaron en su persecución. Varios vehículos de los canales de televisión seguían a la manada casi tan de cerca como los autos de policía. Sin embargo, como si un viento mágico los empujara y sin esfuerzo aparente en su carrera, los animales avanzaban a una velocidad imposible de alcanzar.

Axel, Lou y sus padres, después de una fuerte discusión con el administrador del teatro, se fueron con el resto del público y terminaron de ver por televisión la aventura en la que habían participado personalmente. Los rebaños, siempre a toda velocidad, doblaron por Valde-Grace en dirección a Montmartre. Parecían elegir las calles menos transitadas, como si su guía, el Guanaco Blanco, conociera perfectamente el plano de París. De todos modos la televisión hizo correr la voz y de todas partes salía gente dispuesta a no perderse el extraordinario espectáculo. Los automóviles se apartaban sin daño, una fuerza enorme y delicada parecía detenerlos y sacarlos del camino.

A toda velocidad, los rebaños llegaron hasta Montmartre. Montmartre quiere decir «Monte de Marte» y es, como su nombre lo indica, un monte que forma parte de la ciudad, con la Iglesia del Sagrado Corazón arriba y muchísimos turistas por todos lados.

Así, las manadas tuvieron que abrirse para pasar por los costados de los ómnibus cargados de turistas (sobre todo japoneses) que disparaban sus cámaras de foto y de video con desesperación desde las ventanillas.

- ¡Aquí llegamos! - gritó el Guanaco Blanco-. ¡Aquí está el cerro! ¡Yo soy el Yastay, el Coquena soy, y los cerros se abren para mí!

Y sin disminuir ni por un instante la velocidad, las manadas de animales se lanzaron sobre Montmartre y el monte se abrió para recibirlos. Los vecinos entrevistados contaron después que habían sentido la sensación de un leve temblor de tierra, suficiente para alarmarlos pero no 
como para hacerlos entrar en pánico. Vicuñas, guanacos y su guía entraron en el «cerro» y desaparecieron para siempre de la vista de los policías, los periodistas, los turistas y los vecinos.

Después se habló mucho. Se habló de imágenes holográficas y de trucos de prestidigitación. Se habló de histeria colectiva y de hipnotismo. Las imágenes grabadas pasaron a formar parte del archivo histórico de la ciudad. Sin embargo nadie estaba dispuesto a dedicar mucho tiempo y esfuerzo a un hecho absolutamente extraordinario pero que duró solo media hora casi, sin más consecuencia que la desaparición de todas las monedas de los bolsillos de los espectadores.

La otra consecuencia, para desesperación del administrador, quedó en el teatro: una considerable cantidad de estiércol de camélido (la especie a la que pertenecen el guanaco y la vicuña) desparramado por el local.

Antes de irse, Axel le había dicho para alentarlo que no se preocupara por limpiar porque, según la leyenda, el estiércol que dejan Coquena y el Yastay se convierte a la mañana siguiente en oro puro. Para convencerlo sacó unos pañuelos de papel del bolsillo de su campera, los cargó con un poco de material y se los volvió a guardar.

El administrador del teatro, absolutamente furioso, empezó a descargarse en él de todo el mal rato, insultándolo con una catarata de groserías en francés, que generalmente empiezan con «especie de». Lo llamó especie de imbécil, especie de cerdo, especie de mala persona y otras especies que no vale la pena repetir, hasta que los padres consiguieron llevarse a Axel casi a la fuerza, para impedir que la cosa siguiera con una pelea.

Al día siguiente, en el desayuno, Axel sacó del bolsillo de su campera los pañuelitos de papel que había llenado con bosta de guanaco. Encontró en cada uno un montoncito de oro puro.

Lamentablemente para él, el administrador del teatro había hecho limpiar el local con mangueras esa misma noche. 


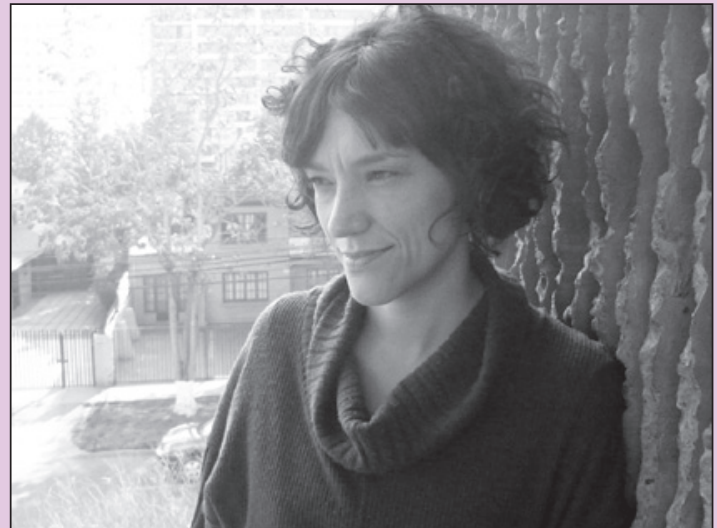

1

Estos poemas formarán parte del volumen Guardianes, que será publicado por la editorial A buen paso.

\section{Guardianes'}

MARÍA JOSÉ FERRADA

\author{
El guardián de los árboles
}

Canta una canción que habla sobre las estaciones. Una canción sobre la luz. Otoño, invierno, primavera, verano.

Las hojas se irán y luego volverán a salir.

El árbol confía.

También nosotros escuchamos ese canto en los jardines.

$\mathrm{Y}$ confiamos.

\section{El guardián de la espuma}

Fabrica un tejido de agua y sal, que deposita con cuidado en el borde de la playa. Lo sostenemos entre las manos un momento.

Quisiéramos hacer con él alfombras para nuestro castillo de arena.

Pero el tejido del guardián de la espuma, dura un momento y luego desaparece, de tan liviano.

\section{El guardián de las palabras}

Mira las cosas.

Y busca el sonido que las nombra:

Riachuelo.

Sol.

Montaña.

Cada cosa se acurruca en un sonido.

Nos gusta nombrar el mundo, acurrucarnos en él.

\section{El guardián de la lluvia}

Su tarea es recoger el agua del cielo, dar forma a las gotas, y ayudarles a bajar hacia la tierra. Llueve.

Abrimos los paraguas.

Llueve.

Y el guardián piensa que, vista desde las nubes, la tierra es un dibujo que se mueve, allá a lo lejos. 


\section{El guardián de la luz de la luna}

Es de noche

y el guardián de la luz de la luna, extiende un velo sobre las cosas.

Océano,

libélula,

pájaros y semillas, descansan.

Descansamos.

\section{El guardián del musgo}

Se encarga de cubrir el tronco de los árboles con hebras que brotan del corazón la tierra.

El secreto de la niebla y de los años.

Todo está guardado en ese manto.

Le pedimos al guardián del musgo que nos regale uno de esos abrigos.

Y nos arropamos. El guardián de las flores

Escucha el despertar del jardín y acude.

Plap

Despiertan las dalias

Plap Plap

Las magnolias

Plap Plap Plap

Las margaritas

Es primavera, nos dice el guardián de las flores.

Nos sostiene una antigua ternura.

\section{El guardián de los pájaros}

Les enseña el vuelo, el canto.

Y nosotros nos sentamos bajo los árboles a escuchar la lección.

Los pájaros arman un alfabeto de trinos y luego lo desarman.

Miramos hacia lo alto y descubrimos los pequeños pupitres,

las partituras.

\section{El guardián de los recuerdos}

Borda en una tela interminable, los días.

Le pedimos que nos deje mirarla y ahí están:

Los veranos.

La casa natal y sus insectos.

El guardián nos presta su caja de hilos y nos deja bordar, sobre los recuerdos, algún dibujo:

estrellas de hilo blanco,

grillos.

\section{El guardián de la noche}

Apaga primero las luces, luego los sonidos.

Nuestra cama es una cáscara de nuez que cuelga del cielo.

Es de noche, susurra el guardián.

Y soñamos. 


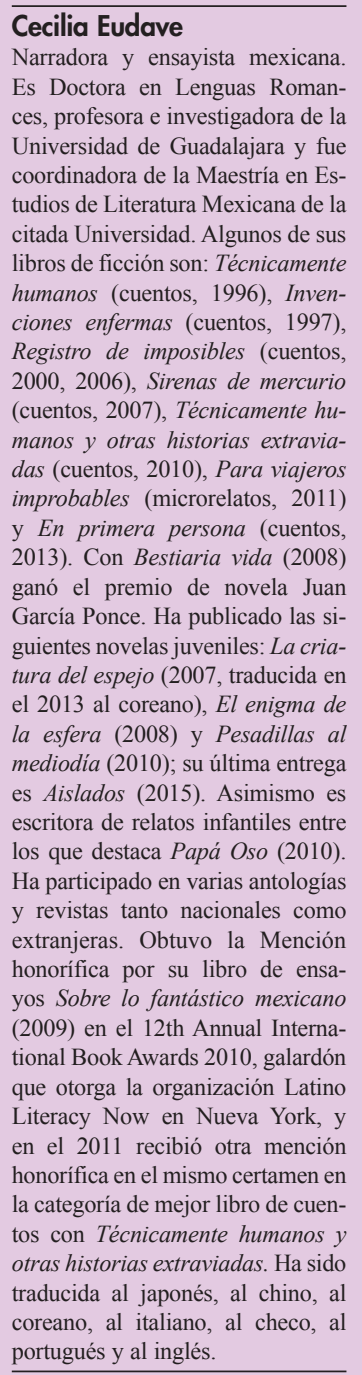

\section{Cecilia Eudave}

Narradora y ensayista mexicana. coordinadora de la Maestría en Estudios de Literatura Mexicana de la citada Universidad. Algunos de su de ficción son: Técnicamente 1996), Inven2000, 2006), Sirenas de mercuri entos, 2007), Tecnicamente huextraviay En primera persona (cuentos, 13). Con Bestiaria vida (2008) vela Juan tura del espejo (2007, traducida en el 2013 al coreano), El enigma de la esfera (2008) y Pesadillas al escritora de relatos infantiles entre extranjeras Obtuvo la Mención honorífica por su libro de ensaque otorga la organización Latino Literacy Now en Nueva York, la categoría de mor libro de cuencon Técnicamente humanos traducida al japonés, al chino, portugués y al inglés.

\section{El expreso azul}

\author{
CECILIA EUDAVE
}

I

La noche es profundamente oscura. No se distingue nada a poca distancia salvo el ruido estrepitoso de los aplausos que salen del auditorio donde ha concluido la charla de monsieur Verne. El auditorio ha quedado complacido, no dejan de ovacionar al escritor que ha despertado el interés de un público muy diverso, sobre todo de científicos que se asombran de la capacidad visionaria de ese hombre cuya imagina-

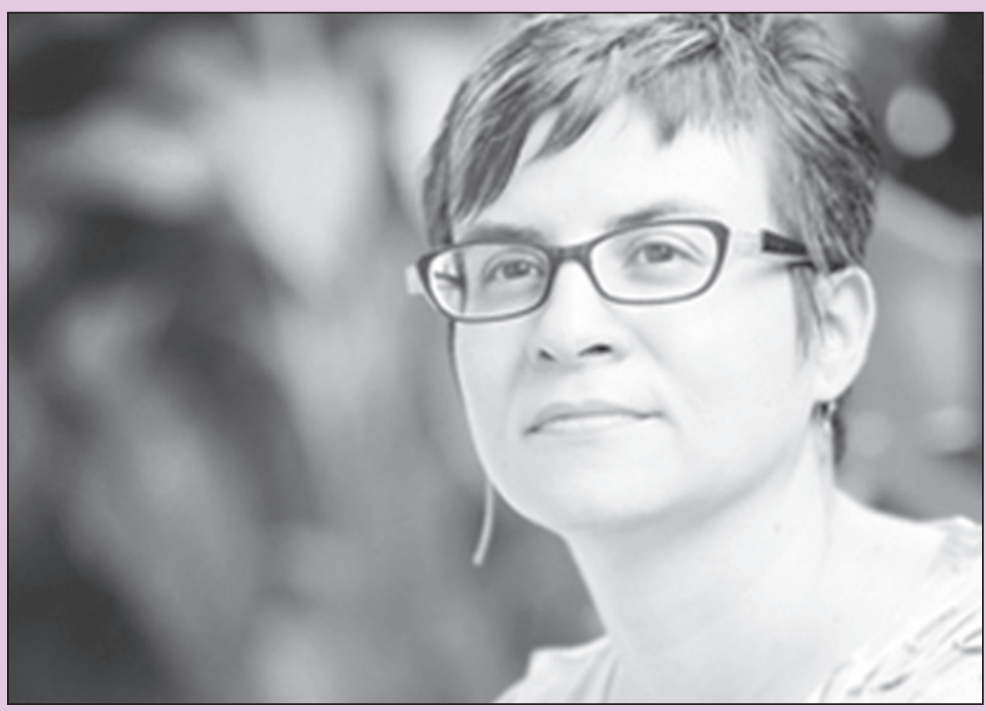
ción está en el rango de lo razonable, de lo posible. Verne mueve la cabeza como incrédulo ante tanta amabilidad y admiración. Sacude las manos entumecidas una y otra vez mientras recoge sus cosas ayudado por su joven acompañante, Paul, un chico de no más de quince años, hijo de un amigo cercano que le permitió traerlo consigo para que le sirviera de compañía y de mayordomo.

Ahora, bajo ese dolor artrítico, se arrepiente de haber aceptado dar la conferencia y de haberse desplazado a su edad a tierras tan lejanas. ¿Qué tenía que hacer en Rusia? Encima está con ese frío que desde que llegó se le coló por la espalda y no deja de recorrerlo sigiloso y lento. De nada valen las mantas, ni las calefacciones, de nada el vodka que le han dado sin parar, ni las sopas, ni las deliciosas carnes sazonadas al más puro gusto ruso. Ni siquiera la gentileza de tener siempre a mano una buena botella de vino francés. Por eso mismo declinó la oferta de quedarse un día más en la capital y pese a la petición de que se marchara cuando hiciera mejor tiempo él se aferró a tomar el tren de regreso a París de inmediato argumentando no sólo el cansancio sino, también, asuntos pendientes de trabajo.

Paul termina de guardar los papeles mientras Verne le da la mano y besa dos veces en la mejilla a Ivannova, la chica que le ha servido de traductora y guía en la ciudad.

- Lo echaré de menos. Fue un placer conocerle.

- Para mí más. Quién diría que a mis setenta y cinco años andaría todavía queriendo ver mundo. Pero qué le voy a hacer, necesitaba - y no lo decía por cumplido - conocer estas tierras tan alabadas por los viajeros, por los aventureros de verdad. 
Ivannova sonríe y lo ayuda a bajar del estrado. Es cuando lo intercepta uno de los distinguidos convidados a la charla. Verne casi se tropieza con él cuando éste le extiende la mano para felicitarlo y, hablando perfectamente su idioma, le pregunta:

- ¿Piensa escribir una tercera parte con el tema del viaje a la luna? Los datos que nos ha proporcionadado esta noche son verdaderamente fascinantes, más creíbles y más auténticos que los que aparecen en sus otras dos novelas. A veces creo que usted en el fondo es un científico renegado, un escritor impostor que, tras la ficción, oculta su talento.

Verne trata de ser cortés. Sonríe ante el comentario, pero piensa que quizá, por impresionar al público una última vez, se ha excedido con tantas hipótesis que, si bien no son descabelladas, le nacen espontáneamente al asociar teorías que otros lanzan por todas partes. Él es un gran ensamblador; eso debería decirle al caballero, que él es un simple armador de rompecabezas, que tiene la capacidad de congregar ideas disímiles y crear una completa, que su imaginación «razonable» crea posibilidades para el futuro. Mas sólo atina a contestar con una frase gastada:

- Todo es producto de esta febril y ahora senil imaginación. Soy un simple escritor de ficciones científicas. Y no, no habrá una tercera parte, esa historia le queda reservada a los hombres.

Y dicho esto, desde el fondo de un pasillo, salido de entre los cortinajes del salón, aparece un hombre de aspecto extranjero; no es ruso y lo reconocen de inmediato los congregados, pertenece a la embajada Estadounidense, es mister Lloyd, que ha asistido a escuchar al escritor. Lo intercepta y agrega:

- Es verdad, toca a los hombres cumplir con sus sueños.

Luego enciende un cigarrillo y lo mira con recelo.

Verne conoce a los yankees, ha estado en Estados Unidos y si algo lo motivó a escribir sus dos libros sobre viajes espaciales fue el encuentro con esa cultura y sus deseos de conquistarlo todo.

- ¡Ah!, los americanos siempre pensando en dominar el mundo.

- Todos desean dominar el mundo, todos.

Ivannova se percata de la tensión establecida en el ambiente y se apresura a interrumpir lo que podría llegar a ser una discusión acalorada. Toma a Verne del brazo:

-Debemos darnos prisa o perderá el tren.

Asiente y con un gesto rápido llama a Paul para que se reúna con ellos. Se despide con gentileza de los caballeros que le acompañan y se aproxima a la salida. Afuera lo espera el coche que lo conducirá a la estación. La modernidad ha llegado a Moscú, pero un carro tirado por caballos es la mejor opción en medio de la nieve y la penumbra.

\section{II}

En la estación Verne se siente asediado por el frío. Paul le ha buscado un banco lejos de las corrientes de aire mientras esperan a Ivannova, quien está colocando el equipaje y asegurándose de que el compartimento y el resto de cosas estén en su lugar. El regreso a París es largo y lento. Mientras tanto el viejo francés piensa en lo que dijo el caballero ruso: «Escritor impostor». Le da un poco de risa. Luego mira al muchacho que ha hecho de todo en el viaje, jes tan joven! Cuánto, cuánto daría él por volver, ya no cincuenta años atrás, pero sí al menos veinte. Se quita la pesada gorra rusa que le han obsequiado, un regalo de parte del Zar Nicolas II, quien aprecia sus libros y ha hecho que sus hijos los lean. Observa el sombrero típicamente ruso y lo acaricia con gusto, la piel es tersa y el interior ha sido forrado con una seda exquisita. En verdad que calienta. Vuelve a colocárselo, pues de pronto entra una ráfaga imperiosa y sorpresiva y, junto con ella, un hombre sombrío y alto que lleva un pesado abrigo negro. Con la mirada rastrea el lugar hasta dar con los dos franceses que se distinguen perfectamente entre la gente local, como los otros escuálidos extranjeros de Europa occidental que no muestran lo adusto de un cuerpo acostumbrado a tiempos temerarios.

- ¿Monsieur Verne?

Asiente con la cabeza y se pone de pie. El hombre, sin volver a dirigirle la palabra, hace un gesto para que lo sigan. Paul, extrañado de no encontrarse de nuevo con la guía de siempre, se aproxima con rapidez para preguntar:

Breve antología

CECILIA EUDAVE 
$-\dot{\text { Ivannova? }}$

- Ella tuvo que marcharse a la embajada francesa a realizar otras tareas. Yo estoy aquí para terminar de gestionar su regreso. Tenga la amabilidad de acompañarme, su tren ha cambiado de vía.

Paul no sabe si obedecer o no. Hay algo en el hombre que no le inspira confianza, sin embargo, y presa del cansancio de las últimas semanas, se deja conducir. Quizá porque desea poderosamente regresar a casa y contarle a sus compañeros de liceo todas las experiencias vividas: los lugares insólitos, los viajes en trenes lujosos, las comidas entre diplomáticos y embajadores. Mientras tanto, el escritor también contiene su recelo hacia ese hombre: se nota que habla mal su idioma y no es de los que conversan, algo extraño para pertenecer al cuerpo diplomático. Pero, ¿qué hacer? Se siente desvalido, vulnerable, todo está en ruso, todos hablan esa lengua profunda y sonora, y no hay nadie a quien preguntar. Por fin suben a un vagón de color azul y son conducidos por un estrecho pasillo que los lleva hasta su compartimento. El hombre abre la puerta; revisa el sitio, sobre todo verifica que la ventana esté bien cerrada; luego comprueba el minúsculo baño, sube y baja la cama litera. «Perfecto», debe haber dicho en ruso, o algo así, pues sale con una sonrisa insólita en ese rostro serio y tenebroso. Paul nota que las maletas no están allí. Mira al extraño sujeto y como si éste adivinara su pensamiento se adelanta a la pregunta:

- Su equipaje por error fue enviado a otro vagón, ya vienen de camino, pero el tren es largo, sean pacientes.

Dicho esto los invita a tomar asiento, pues en breve el tren partirá. Ya se ha escuchado la tercera campanada emitida por el jefe de la estación. Paul logra distinguir su inconfundible gorra roja en medio de la escasa luz amarillenta del andén. La máquina, obedeciendo al toque, arranca y hace un leve jaloneo que los obliga a sentarse de inmediato. El hombre se despide con cortesía y sale cerrando la puerta con llave tras de sí. Paul escucha ese clic extraño, se levanta presuroso de su asiento y con asombro desmedido comprueba aquello que no entiende: los han dejado encerrados. Verne se aproxima, entre los dos intentan forzar la puerta para abrirla. El chico grita, golpea la puerta, mas todo su esfuerzo es sofocado por las cornetas poderosas del misterioso Expresso azul en el que los han montado. Y ahora van sin dirección y sin rumbo, adentrándose entre las vastas praderas blancas.

\section{III}

Han pasado varias horas desde que los confinaron en ese compartimento. Verne ha permanecido callado, escuchando el malestar, el miedo, el odio y la desesperación de Paul, que no ha parado ni un momento y que se mueve de un lado a otro como si su adrenalina no acabara de asentarse. El escritor está tranquilo, ha escrito infinidad de novelas de aventuras y conoce el sistema: no tardarán en aparecer los hechos que expliquen el por qué los tienen ahí y cuales son la malas intenciones de sus raptores.

Aislado por completo de las quejas y lloriqueos de su acompañante, investiga el sitio donde los han alojado en busca de pistas. Sin duda van en un vagón de lujo: el terciopelo color frambuesa de las paredes, la pantalla rosa y encintada de la lámpara sobre la mesilla junto a la ventana, los espejos biselados, todo enchapado en fina caoba, las cortinas verdes, el baño impecable, casi nuevo. Por otra parte no ha escuchado un solo ruido en los compartimentos contiguos, lo cual indica que están vacíos, quizá todo el coche donde viajan lo esté. Busca en el minúsculo baño algún indicador del nombre de su transporte: nada. Paul se sienta al fin y observa fijamente la ventana:

- Puedo intentar salir por ahí, trepar hasta el techo, deslizarme con cuidado hasta llegar a otro vagón. Ya está amaneciendo, alguien debe ayudarnos, hemos sido raptados...

Verne sin perder la calma replica:

$-¿$ YY quién te ha confirmado eso? Probablemente todo es un malentendido - no lo cree pero intenta calmar al chico-. Rusia atraviesa tiempos difíciles, de cambio. Tal, tal vez nos tienen aquí por nuestra seguridad...

No termina de argumentar sobre las extrañas circunstancias de aquel enredo cuando el hombre del abrigo negro abre la puerta y entra pistola en mano. Detrás de él aparece un sujeto 
bajito con el desayuno. Ahora queda claro, no hay ningún malentendido, la cosa pinta mal y ellos no tienen ni idea de a dónde se dirigen. Verne pone al chico tras su espalda mientras dejan la bandeja sobre la mesita. Permanecen inmóviles, pues son vigilados por el cañón del arma.

- Al menos díganme a dónde nos llevan.

No hay respuesta. Los vuelven a encerrar y se oye como los dos sujetos se alejan por el pasillo. Paul enfurecido, perdiendo la paciencia, intenta abrir con todas sus fuerzas la ventana. Las venas se hinchan en su rostro. Verne lo controla de inmediato y le ordena bajar.

- Necio. Mira el cristal, ¿̇ves esas ramas de hielo delicadamente trazadas por el invierno? ¿Observas cómo escarchan todo y no son vencidas ni por la velocidad del tren? En Francia es posible que tuvieras una oportunidad si lograras salir a la intemperie, pero

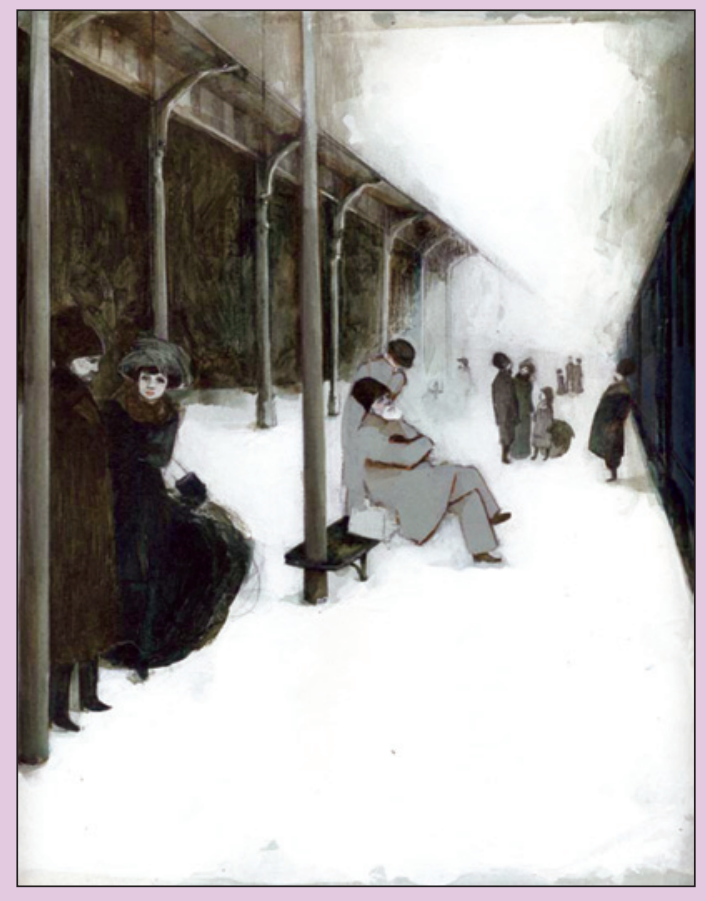
en Rusia sería una imprudencia mortal; el frío siempre está al acecho de su presa - sonríe nostálgico - créeme. Gauthier no mentía cuando dijo que el invierno de estas regiones puede introducir su monstruosa pata de oso en un segundo y herirnos con su garra.

El chico desiste. La mirada severa de Verne se apacigua.

- Comamos algo, pensaremos con más lucidez. Después durmamos: el cuerpo debe estar descansado. Son las reglas de un aventurero - piensa con ironía - y por curioso que parezca el escritor de novelas está inmerso en una.

\section{IV}

Llevan dos días sin salir de allí. El tren ha parado numerosas ocasiones en estaciones oscuras y desoladas pero no han podido distinguir ningún rastro conocido. Si de algo están seguros es de que no van rumbo a Europa occidental sino que, al contrario, se están adentrando en el territorio ruso. Paul no cesa de mostrar un letrero improvisado donde ha escrito «Au secours», pero nadie se aproxima a ese vagón, parece un fantasma enganchado a un enorme cuerpo metálico que se niega a soltarlos. Han logrado distinguir la longitud del tren, un kilómetro, quizá más, es larguísimo, demasiado. Verne ahora sí muestra signos de verdadera preocupación:

-Es el transiberiano, Paul. Viajamos en el tren y en la ruta más extensa del mundo.

Va a agregar algo más cuando escuchan una voz queda detrás de la puerta:

- Monsieur Verne, ¿está usted ahí?

Los franceses se miran desconcertados y finalmente el chico contesta:

-Sí, aquí está. Nos tienen encerrados.

-Lo sabía. No se preocupen voy a rescatarlos. Pero debemos esperar, en unas horas llegaremos a la siguiente estación, entonces procederé...

- ¿Unas horas? Llevamos días encerrados.

Paul no puede más con su angustia. Verne lo hace callar y habla:

-Esperaremos. Pero ¿quién es usted?

-Un amigo - ríe-. Soy mister Lloyd y despreocúpese lo sacaré de allí.

Dicho esto su sombra desaparece y su voz tras él. Con esa nueva esperanza se mantienen cuerdos. Verne hace algunas anotaciones y de vez en cuando intenta leer un libro. El chico escribe garabatos sobre una libreta donde ha hecho anotaciones de su viaje. Las horas pasan lentísimas como si el frío paralizara hasta el tiempo, lo que hace aquella espera insoportable. 
Por fin el tren se detiene en una estación donde domina un silencio espectral. Verne puede observar cómo sólo sube un pasajero y nadie baja. Luego el tren continúa su marcha.

Una hora después se abre la puerta sin aviso y entran dos hombres, uno toma a Paul a la fuerza, a pesar de que éste hace su mejor esfuerzo para liberarse; el otro amaniata a Verne para que no intervenga. Sin dar ninguna explicación se llevan al chico, dejando al escritor abandonado a la incertidumbre. Minutos después regresa el hombre del abrigo negro:

- Vendré a por usted para la cena. Conocerá a alguien muy importante para nuestra causa. Si intenta alguna tontería el chico paga las consecuencias.

Verne, impecablemente vestido, atraviesa los largos y estrechos pasillos del tren. Comprueba que en su vagón no viaja nadie. Cruzan algunos otros y nota cantidad de viajeros, la mayoría rusos, quizá un par de ingleses, algunos chinos, seguramente, ricos potentados del tráfico de té. Todos los pasajeros en lo suyo, ninguno le presta atención. Avanzan varios vagones más. Están próximos al restaurante - intuye Verne-, pues son persistentes las emanaciones agrias de la solianka, esa sopa de repollo que han comido sin parar desde su partida de Francia. Cuando entra en el vagón se sorprende de que sólo al final del mismo se encuentre una figura vestida de negro.

Un camarero se aproxima a recoger su sombrero y su abrigo. Luego le brindan una copa de champán. Es majestuoso el coche-restaurante, cargado de una elegancia aristocrática y, si no fuese porque sabe que lleva días viajando y que efectivamente no ha bajado del tren, no podría creer que aquel lugar fuera enganchado a una maquina que atraviesa el desierto blanco.

Toma asiento junto al extraño anfitrión que parece haber terminado de cenar. Verne, sin dejar de admirarse de la exquisitez de la vajilla, de las copas, de las arañas de cristal cortado que penden cadenciosas, escucha al misterioso hombre decir:

-Es triste que la belleza aniquile a tanta gente en mi país. Que sólo sea para unos pocos levanta una copa de fina manufactura y la estrella contra el piso-. Pero usted sabe de eso, creó a ese magnífico rebelde Matías Sandorff - y, percibiendo la incomodidad de Verne, añade-. Soy Vladímir, basta con que sepa eso. No soy su enemigo, sólo quiero que me dé cierta información. Seré directo, lo necesitamos para la causa. Hemos descubierto que tiene una capacidad poco común de acertar al seleccionar lo posible de lo imposible en el plano de lo científico. No dudo que en breve sus máquinas fabulosas sean una realidad. Cielo, mar, tierra, eso ya lo tenemos contemplado. Pero me he obsesionado también con el espacio. Le puedo parecer un simple y llano hombre, pero créame soy el futuro. Soy lo que el mundo conocerá en las próximas décadas. Y ¿ sabe por qué? Porque me anticipo. Los gobiernos, los nuevos gobiernos que yo unificaré y encabezaré, están años por delante de sus ciudadanos, se preparan para cualquier vicisitud y yo creo que el futuro, el verdadero futuro, se encuentra en el espacio. Está la luna, por supuesto, pero la órbita de la tierra es lo que deseo vigilar desde lo más alto, controlar desde ahí. Nadie podrá alcanzarnos... - nota que se ha emocionado de más y no quiere evidenciar sus planes-. Pero eso a usted no debe importarle por ahora.

- ¿Qué quiere de mí?

Hace una seña para que empiecen a servirle la cena.

- Usted será uno de mis asesores en la carrera para conquistar el mundo.

- ¿Por qué algunos hombres están obsesionados con eso?

- Algunos no, todos - se limpia la boca y se pone de pie-. Y más vale que no haga ninguna tontería.

Mueve la cabeza y enseguida aparece mister Lloyd atado y golpeado terriblemente. Sus ojos reflejan un terror absoluto. Vladímir hace un ademán, sus soldados levantan al americano y abriendo una de las ventanas, que deja entrar una ráfaja atroz, lo tiran como a un desperdicio. Verne queda horrorizado.

- Ahí va uno menos de los que desean gobernar el mundo. Y eso mismo le pasará al chico si usted no se atiene a mis órdenes. En tres días más llegaremos a nuestro destino. Yo bajaré en la próxima estación pues no es seguro que viaje de esta forma. Mis enemigos avanzan conforme mi fama por el mundo. 
Va a retirase. Verne nota que ha hurtado su portafolios de su compartimento. Vladímir se percata de ello y agrega:

-Interesantes apuntes. Se los entregaré después en lo que será su nuevo hogar. Disfrute de la cena.

Dicho esto abandona el lugar rodeado por un halo oscuro.

\section{VI}

Paul está amordazado. Lo tienen cautivo en un vagón litera vacío. Antes de acabar ahí, ha pasado por la cocina y por algunos otros vagones iguales a ese, la diferencia era que iban repletos de rusos, chinos, mongoles, cantidad de idiomas y de olores mezclados, creando una pequeña babel encerrada en un largo y poderoso Expresso azul. No había podido hacer gran cosa para comunicarse: había dejado caer un papelito con su incansable «Au secours» que para su mala suerte recogió una señora china para entregárselo de inmediato. Él quiso negar que fuera suyo, pero el hombre del abrigo negro lo tomó agradeciendo el gesto de la asiática. Tras leer el papel su rostro se volvió todavía más adusto. Una vez llegados a donde ahora se encuentra, le propinó tremenda bofetada: «Otra tontería por tu parte y te tiro del tren» dijo.

El chico intenta liberarse las manos, lo hace disimuladamente aprovechando que el tipo fuma despreocupado mientras mira a través de la ventana. Amanece. Si no fuera porque va atado disfrutaría de ese paisaje uniforme y bello: miles de árboles pasando uno de tras de otro en total armonía simétrica. Deben de ser los Urales, piensa. No está nevando y un sol espectacularmente nítido se asoma por entre todas esas ramas creando un caleidoscopio de colores dorados. Están quietos, no parecen agitarse por el viento, quizá el clima ha cedido un poco. Quizá tiene una oportunidad de abandonar ese lugar si logra zafarse; el hombre del abrigo ha dejado entreabierta la puertezuela del vagón para que escape el humo de su tabaco. Es ahora o nunca, y con todas las fuerzas de las que dispone e hinchando su cara por la presión que ejerce sobre la soga, insólitamente logra liberar una mano. El tipo apaga su cigarrillo y mira al chico que de inmediato trata de volver a acomodarse:

- Voy por el desayuno. Si intentas algo te mato.

Paul mueve la cabeza en señal de entendimiento. En cuanto su guardián sale, se apresura a desatarse. Se abrocha la chaqueta, se acomoda el gorro. Necesita protegerse más si desea soportar el clima de afuera. Busca en el vagón y encuentra los guantes del hombre y una bufanda desmedidamente larga. Toma unas cuantas mantas y se improvisa un atuendo para el frío. Con la bufanda se sujeta bien las mantas. Sin pensarlo más, sale. El clima es insolente, el aire casi congela de entrada su rostro. Lo siente estirado, tanto que parece rasgarse. No hay manera de arrepentirse.

Con mucha decisión sube por la escalinata y llega hasta el techo. El tren ha bajado su velocidad desde hace un rato, seguro que se aproximan a una estación. Sin embargo no puede quedarse ahí hasta llegar a ella. Debe moverse, y rápido, o morirá congelado. Decide que es mejor arrastrarse para evitar una caída y eso hace. No sabe si lo logrará, las articulaciones comienzan a entumirse y le duele todo el cuerpo. Mas prefiere morir por las garras del oso polar ruso que por un tipo malintencionado. Mientras tanto, el hombre ha regresado con la comida. Inmediatamente nota que el chico ha desaparecido, la puertezuela del vagón abierta. Suelta la bandeja y saca un revólver. Con agilidad sube hasta el techo y descubre a Paul arrastrándose con dificultad. Se aproxima con cautela para no resbalarse. Al estar a la distancia adecuada, le grita:

- Te dije que si hacías algo te mataba. No me dejas opción.

El chico se paraliza al escuchar esa voz ronca y amenazadora. Se gira para ver a qué distancia de él está el hombre y se percata de que le apunta con la pistola, lo tiene en la mira. Asustado, el joven cierra los ojos. Se escucha un disparo. Desconcertado Paul abre los ojos y nota como su captor cae para perderse entre la nieve. Luego observa en la escalinata del lado al que se dirigía una figura que le extiende la mano. Se estira hasta alcanzarla. Es arrastrado con fuerza e introducido de nuevo en el vagón. Su salvador se descubre: es Ivannova. La abraza instintivamente a pesar de que el grado de congelación de su cuerpo es terrible. La mujer lo percibe y se asusta. Las manos y el rostro están morados. Apenas puede caminar. Grita y dos jóvenes aparecen para ayudarla a llevar a Paul hasta la cocina.

Breve antología 
Una vez allí, ordena que le llenen de agua caliente varias ollas. Introduce los pies y las manos del chico en ellas. Luego con un mantel cubre su cuerpo para que el vapor que desprende la cazuela más grande ayude a desentumecer su rostro. Cambian el agua cada media hora, lo hacen unas cuatro veces hasta que el chico comienza a sentir mejorías. Ivannova nota con satisfacción que la cara ha vuelto a recuperar su tono rosado y que las manos y los pies también. Le acerca un poco de sopa para que la beba, eso acaba de volverlo a la vida. Entonces la antigua guía pregunta:

$-¿$ Puedes caminar?

- Sí, ya me siento mucho mejor - dice Paul, levantándose con dificultad-. Tenemos que ir por monsieur Verne. Lo tienen encerrado - sus palabras se tropiezan unas con otras -, lo iban a llevar a ver a un hombre importante.

- Tranquilo, lo sé todo. Tenemos que ir a por él, deben bajar de este tren.

\section{VII}

Cuando el escritor ve entrar a Paul lo abraza sin reprimirse. Luego distingue a Ivannova y retrocede un poco poniendo al chico detrás de él.

- Tranquilo, ella me salvó la vida, es amiga.

-Ya no sé en quién confiar.

-Y hace bien. Son tiempos de cambio, violentos, todos desconfían de todos - dice tranquilamente Ivannova.

Notando la expectación de Verne se explica:

- Yo pertenezco a una organización internacional que vela por la seguridad - duda en decirlo- del mundo, por simplificar las cosas. Estamos en contra de las guerras y de la codicia que han demostrado los dirigentes actuales. Incluso, hemos evaluado los cambios venideros y no son del todo favorables. Aquí mismo en mi patria se gesta un movimiento revolucionario, pero su líder deja mucho que desear y lo que finalmente puede pasar es que sólo el poder cambie de manos. Nosotros no podemos evitar lo inevitable, ni actuamos con violencia - luego mira al chico - a menos que sea necesario y la vida de inocentes corra peligro. Pero si bien no podemos erradicar a estos hombres sedientos de poder, sí intentamos que terceras personas no se vean involucradas o sean dañadas para alcanzar sus fines. Y usted monsieur Verne ha despertado la codicia de muchos: de los americanos, ya vio el triste fin de mister Lloyd; de los ingleses, tenemos a dos detenidos en sus compartimientos: viajaban en este tren con las mismas intenciones que Vladímir.

- Pero si yo sólo soy un escritor de novelas de aventuras.

-Es un visionario. Un hombre con una capacidad asombrosa de distinguir lo verosímil de lo inverosímil. Los científicos más doctos trabajan sobre eso que a usted le ha dado por llamar imaginación febril pero razonable. Lo necesitan porque es precisamente de lo imaginario de dónde surgen las grandes ideas que mueven al mundo. Ellos creen que está trabajando en una tercera entrega sobre viajes espaciales. Y no bastándoles la Tierra, ahora quieren la Luna y la órbita de la Tierra; no les importa el tiempo que tarden, ni a quién tengan que eliminar en su camino.

${ }_{-} \mathrm{i} \mathrm{Si}$ yo escribo por divertirme!, todo es un juego.

-Jugando, así han empezado los grandes descubrimientos.

- ¿Qué hacer?

-Eso no lo sé. Por lo pronto debemos sacarlos del Transiberiano pues lo espera un grupo de científicos al final del recorrido. En breve nos detendremos en la estación Karimskoïe, allí dos de mis hombres los esperan para llevarlos a tomar el Transmanchuriano. Si todo sale según lo planeado, en menos de dos horas habrán cruzado la frontera. Los rusos no podrán tocarlos. Harán el trayecto completo hasta su destino final, Port-Arthur. Allí estará Lu, una compañera de la organización. Ella los llevará hasta un barco seguro. Nada lujoso pero aceptable, un carguero chino de té que va rumbo a Inglaterra. Ustedes deben actuar como si no pasara nada - les da unos pasaportes falsos-. Estas son sus nuevas identidades, por lo menos hasta llegar a Francia. La aventura no ha terminado. 
Verne, sorprendido ante lo que ha escuchado, cae abatido sobre el sillón del compartimento. Luego mira a Ivannova con tristeza:

- No había querido confesarlo porque no sabía si terminaría esa novela, pero, sí, he estado escribiendo una tercera parte sobre el tema de la conquista de la luna, sobre como salir de órbita, sobre satélites artificiales y sobre una guerra en el espacio. Y todo eso lo tiene Vladímir...

- También lo tenía mister Lloyd, mandó copiar todo el manuscrito antes de que diera su conferencia en Moscú. Y creo que los Ingleses lograron conseguir algunos fragmentos, junto con los alemanes y austrohúngaros que mantienen un perfil bajo.

El escritor abre sus ojos descomunales ante aquella revelación. No puede creer que esté pasando aquello y con una tristeza enorme piensa que es cierto que la realidad supera a la ficción.

\section{VIII}

Después de casi cinco días de trayecto en tren ponen pie en tierra firme. El aire refresca los rostros de Verne y Paul. Ivannova los conduce al Transmanchuriano. Un par de jóvenes de Mongolia serán sus custodios hasta llegar a Port-Arthur. La mujer revisa por última vez que todo esté en orden. Baja del vagón y se despide dándoles un abrazo fuerte y dos besos en las mejillas.

- Venga con nosotros Ivannova, aquí correrá peligro.

-El peligro está en todas partes, prefiero enfrentarlo en mi tierra y ayudar a mi gente a sobrellevarlo.

Verne admira la templanza soberbia de esa mujer y vuelve a abrazarla fraternalmente. Suena la tercera campanada del jefe de estación, el tren se jalonea para ponerse en marcha. Agitan la mano despidiéndose de Ivannova antes de entrar al vagón. Ésta devuelve el saludo y lanza una última sentencia:

- Monsieur Verne, yo también tendría cuidado con los chinos...

Sólo alcanza a escuchar esa oración inconclusa pues el tren se aleja rápidamente dejando la figura de su amiga perdida en el horizonte, junto con el resto de sus palabras. El escritor frunce el ceño como signo de un mal presentimiento y mirando al chico agrega:

-Paul, me temo que nos queda un largo camino a casa... 
